Portland State University

PDXScholar

5-6-1974

\title{
Colored Light: a Brief Study of Stained Glass Windows, Including a Self-Guided Tour of Stained Glass in West Portland
}

L. Jean Connors

Portland State University

Follow this and additional works at: https://pdxscholar.library.pdx.edu/open_access_etds

Part of the Art Education Commons

Let us know how access to this document benefits you.

Recommended Citation

Connors, L. Jean, "Colored Light: a Brief Study of Stained Glass Windows, Including a Self-Guided Tour of Stained Glass in West Portland" (1974). Dissertations and Theses. Paper 2092.

https://doi.org/10.15760/etd.2090

This Thesis is brought to you for free and open access. It has been accepted for inclusion in Dissertations and Theses by an authorized administrator of PDXScholar. Please contact us if we can make this document more accessible: pdxscholar@pdx.edu. 
AN ABSTRACT OF THE THESIS OF L. Jean Connors for the Master of Science in Teaching presented May 6, 1974.

Title: Colored Light: A Brief Study of Stained Glass Windows, Including a Self-Guided Tour of Stained Glass in West Portland APPROVED BY MEMBERS OF THE THESIS COMMITTEE:

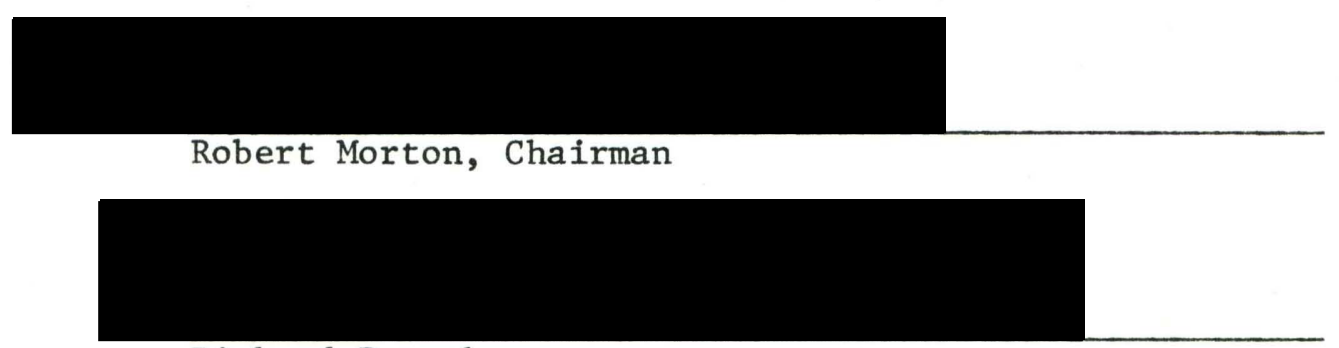

Richard Prasch

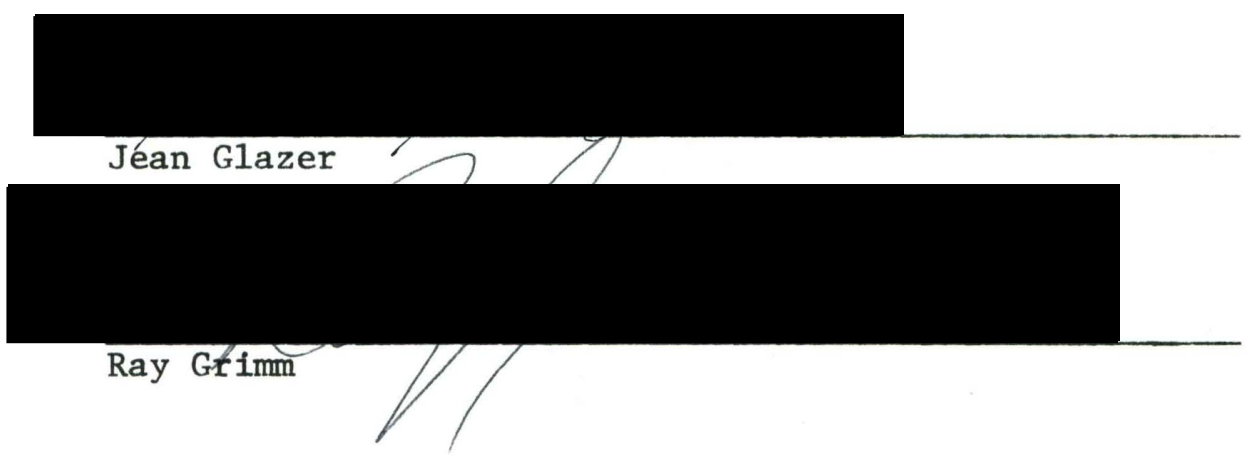

The goal of the thesis was to make available a reference for the beginning appreciation of stained glass windows. It was designed for the person who has no prior experience in stained glass, and therefore the information is kept general and non-technical. A short history of stained glass is contained within the first section, and the second section is a self-guided tour of stained glass in West Portland.

The historical information was pieced together from the library resources of Portland State University. The subject itself is difficult, 
as extensive reference material and primary sources are simply not available.

The second section was designed specifically for the Portland resident. Seven churches and a synagogue were selected within walking distance of one another. A map is included, and the reader is urged to take this self-guided tour. The data was gathered from church records, newspaper articles, the Oregon Historical Society, professional glass craftsmen and signatures on the windows. After extensive research, it is discouraging to note that almost no information on Portland stained glass is available. This is attributed in part to the attitude of many of the relative unimportance of stained glass, and the habit of church records and newspaper accounts to limit their reports to personalities rather than facts.

Since the basic theme of the thesis deals with a visual art, it was necessary to relate as much visual information as possible. Twenty-five photographs were chosen from reference books, the British Museum, the Oregon Historical Society and private collections. Calligraphy, maps and drawings are also included.

The thesis is limited in scope and written primarily for Portland residents and visitors. It is an introduction which presents no conclusions. It is a beginning reference for those who have just begun to take notice of stained glass. 
COLORED LIGHT: A BRIEF STUDY OF STAINED GLASS WINDOWS, INCLUDING A SELF-GUIDED TOUR OF STAINED GLASS IN WEST PORTLAND

\author{
by \\ L. JEAN CONNORS
}

A thesis submitted in partial fulfillment of the requirements for the degree of

MASTER OF SCIENCE

in

TEACHING

Portland State University

1974 
TO THE OFFICE OF GRADUATE STUDIES AND RESEARCH:

The members of the Committee approve the thesis of

L. Jean Connors presented May 6, 1974.

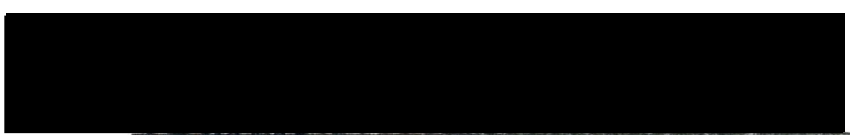

Robert Morton, Chairman

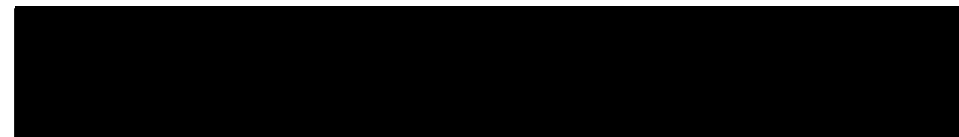

Richard Prasch
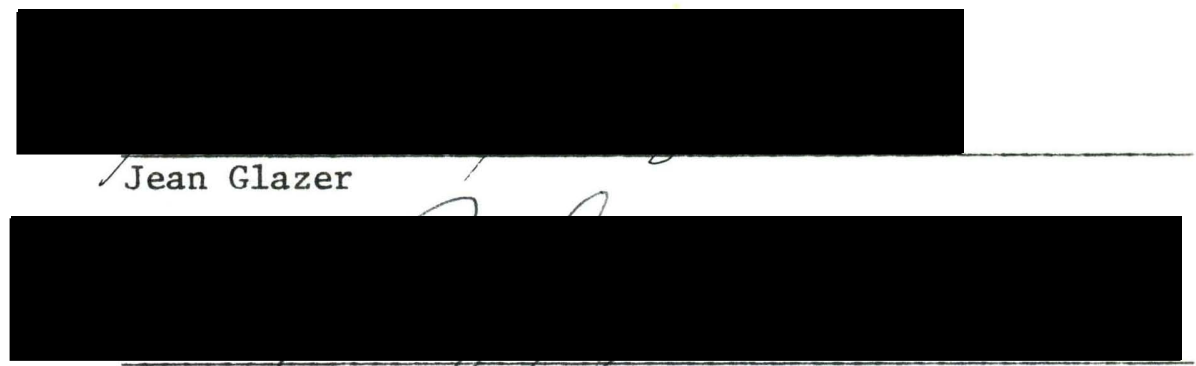

Ray Grimm

APPROVED :

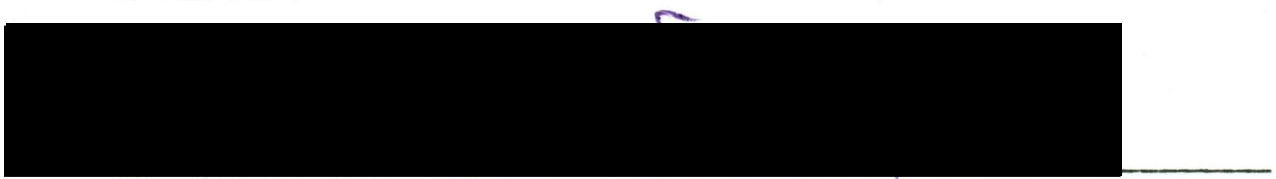

Frederick Heide1, Head, Art Department

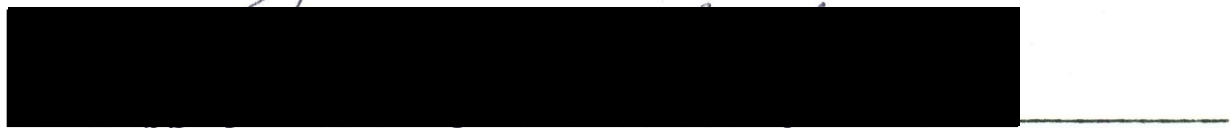

David Clark, Dean of Graduate Studłes and Research 


\section{PREFACE}

"This is the law of creation, the law of maintenance, the law of evolution. Something is created, it is maintained, and while it is maintained it evolves, teaches the height of evolution and then dissolves. This cycle of creation, maintenance, evolution and dissolution continues and in this continuity the life of the universe flows on."

Maharishi Mahesh Yogi 
TABLE OF CONTENTS

PAGE

PREFACE ............................. 111 LIST OF FIGURES . . . . . . . . . . . . . . . . . . . . . vi

SECTION ONE

A BRIEF STUDY OF STAINED GLASS FROM EGYPT TO CHARTRES

I TIME TABLE ........................ . . . . 2

II EGYPT . . . . . . . . . . . . . . . . . 5

II INTERLUDE . . . . . . . . . . . . . . . . . . . . 7

IV GOTHIC ........................ 11

CALLIGRAPHY

Abbot Suger: From the Material to the Immaterial . . . 12

Abbot Hamon: On the Buflding of Chartres . . . . . . . 15

George Duby: Symbolism of the Rose Window . . . . . . 20

SECTION TWO

A SELF-GUIDED TOUR OF STAINED GLASS IN WEST PORTLAND

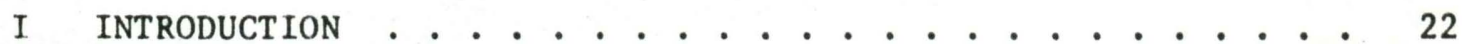

II MAP . . . . . . . . . . . . . . . . 25

III FIRST CHRISTIAN . . . . . . . . . . . . . . . 27

IV FIRST CONGREGATIONAL .................... 30

V SAINT JAMES LUTheran . . . . . . . . . . . . . 33

VI OLD CHURCH. . . . . . . . . . . . . . . . 36

VII FIRST BAPTIST . . . . . . . . . . . . . 39 
VIII FIRST PRESBYTERIAN . . . . . . . . . . . . . 42

IX TRINITY EPISCOPAL . . . . . . . . . . . . . . . 46

$\mathrm{X}$ TEMPLE BETH ISRAEL . . . . . . . . . . . . . . 49

FOOTNOTES . . . . . . . . . . . . . . . . . . . 52

SELECTED BIBLIOGRAPHY . . . . . . . . . . . . . . . . 55

APPENDIX . . . . . . . . . . . . . . . . . 56

CREDITS . . . . . . . . . . . . . . . . . 65 
1. Fall of the Angels 1420 A. D. . . . . . . . . . . . . . 6

2. Dav1d, Dantel, and Jonah 1065 A. D. . . . . . . . . . . 9

3. Bohem1a Glass Workers 15th Century . . . . . . . . . . 10

4. Ornamental Grisa11le First Half 13th Century . . . . . . . . 13

5. Chartres Cathedral: Deta1l, Virgin and Child Center Section about 1145 A. D. . . . . . . . . . . . . . 14

6. Chartres Cathedral: Deta1l, Solomon before 1240 A. D. . . . 17

7. Chartres Cathedral: Rose Window before 1240 A. D. . . . . . 19

8. Hand Rolling Glass in Portland . . . . . . . . . . . . 23

9. F1rst Christian Church: Exterior . . . . . . . . . . . 27

10. First Christian Church: Deta11, Povey S1gnature . . . . . 28

11. First Congregational Church: Exterior . . . . . . . . 30

12. F1rst Congregational Church: Deta11, West C1rcular . . . . 32

13. Saint James Church: Deta11, North . . . . . . . . . 33

14. Salnt James Church: Mission League . . . . . . . . . . . 35

15. 01d Church: Exterfor . . . . . . . . . . . . 36

16. Old Church: Consider the Lilles . . . . . . . . . . . 38

17. First Baptist Chuxch: Exterior . . . . . . . . . . . 39

18. F1rst Baptist Church: Deta11, Gerlach S1gnature . . . . . 41

19. First Presbyterian Church: Exterior . . . . . . . . . 42

20. First Presbyterian Church: Deta11, East . . . . . . . . 43 
21. First Presbyterian Church: Vestibule........... 45

22. Trinity Episcopal Church: Detail, Connick Signature . . . 46

23. Trinity Episcopal Church: North Entrance Way . . . . . 48

24. Temple Beth Israel Synagogue: Exterior ......... . 49

25. Temple Beth Israel Synagogue: Torah .......... . 50 
SECTION ONE

A

BRIEF

STUDY

OF

STAINED GLASS

FROM

EGYPT

To

CHARTRES 
GLASS AND WINDOWS FROM EGYPT TO CHARTRES

2000 B.C. Excavations of Beni Hasam, Egypt. Fragments of flat poured glass, probably formed part of a translucent window inclosure.

1580- New Kingdom Egypt. First evidence of extensive glass

1085 B.C.

production.

600 B.C. Assubanidal's cuneiform tablets. Glass composition same as used today.

Before Far Eastern windows made by arranging small gem-like pieces 306 B.C. of glass in perforated wooden or stone panels.

206 B.C.- Han Dynasty. First known glass production in China. Glass 220 A. D. used to decorate bronze vessels.

200 B.C.- Pompeii. Clear glass windows set directly into sma11

79 A.D.

openings in stone work, also held in place by bronze lattice fixed with nuts and screws.

100 B.C. Invention of the blowpipe in Syria. Mass production now possible.

New Testament references to glass:

I Corinthians 13:12

II Corinthians $3: 18$

James $1: 23$

Revelations $4: 6$

Revelations 15:2

Revelations 21:18 
300 A.D. Cologne. Center of glass production for Roman Empire.

337 A.D. Predentius writes of St. Paul's beyond the walls of Rome, "In the windows are displayed glass of varied colors, as brilliant as the fields of flowers in spring."

400 A.D. Clear glass windows used in Constantinople. Contemporary poet's description of the installation of a Byzantine window in a church at Lyons.

550 A.D. Venetians and Near Eastern craftsmen installed glass windows in the first Notre Dame of Paris.

6th Century First glaziers guild established in France.

A. D.

Windows are mentioned by St. Jerome.

St. Gregory writes that the glass panes of the church of Yzeures-sur-Creuse were removed by a thief who thought they were infused with precious metals.

680 A.D. Benedict Biscap, Abbot of Wearmouth, sent to Gaul for glaziers to install windows in churches at Jarrow and Wearmouth.

743 A.D. Winter palace of the Ommiad caliph Hisham, at Khirbat a1Mafjar near Jericho. Finest examples of window technique developed in Islamic East. Pieces of glass held together in stucco trellis, alternating stucco and glass to create architectonic and plant motifs.

864 A.D. Stories of St. Ludger (d. 809 A.D.) tell of a blind maiden who regained her sight as the light of dawn began to reveal the figures in the glowing windows.

905 A.D. Chronicle of St. Remy of Rheims mentions that windows told various stories. 
979 A.D. Limoges, France. Venetian colony of glass workers accredited with inventing the technique of permanently painting on glass.

969- Adalberon, B1shop of Rhe1ms rebullt his cathedral and 988 A.D. decorated it with figurative windows.

1065 A.D. Prophet windows in Augsburg, Bavarla. Belleved to be the oldest complete stained glass windows in existence.

1081 A.D. "Ascension" windows at Le Mans.

1134 A.D. Cistercian Order forbade the use of colored glass, figures, or crosses. Clear glass only; did permit plant or geometrical motifs.

1140 A.D. Abbot Suger rebu1lds h1s church.

1194 A.D. Chartres west front survives the fire, saving three large Romanesque windows.

1200- W1ndows of Chartres completed. 1240 A.D. 
EGYPT

The first evidence of extensive glass production begins in Egypt in the New Kingdom (1580-1085 B.C.). The Egyptian developed three distinct techniques for working glass. The first and oldest was simply making glass, which was later cut and polished for inlay and jewelry. Glass was so difficult to make that the value of an imitation glass ruby was as much as the ruby itself. The second method was borrowed from bronze casting. Small vessels were made by casting and rolling hot glass onto a solid sand core, which was later removed. The third development was in making flat glass, which was then used in combination with stucco to create,

- . a translucent screen for sealing windows and other types of apertures. The excavations of Beni Hasam in Egypt have brought to light fragments of flat poured glass, which date from the beginning of the second millenium B.C., and probably formed part of translucent window closures. 1

Egypt, Mesopotamia, and most of the Mediterranean produced glass, and by 100 B.C. the Syrian knowledge of iron made possible the invention of the blowpipe. Mass production was now possible, and Roman civilization became in part economically dependent upon glass. 2 


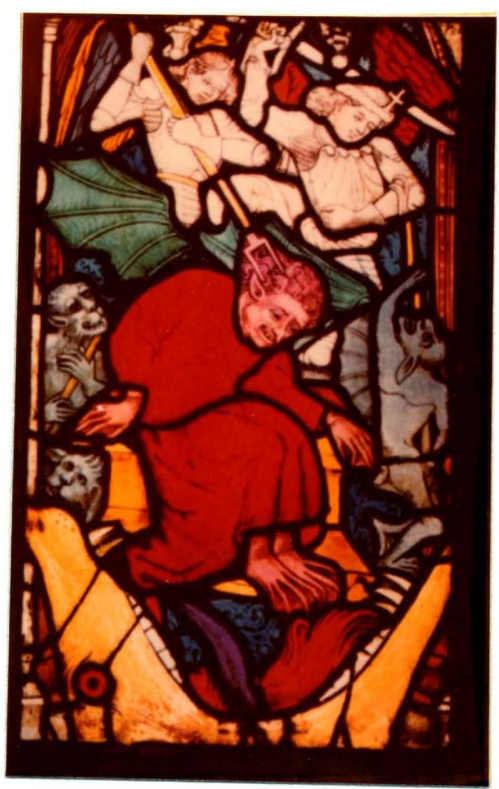

Figure 1. Fall of the Angels 1420 A.D. 
INTERLUDE

The evolution of windows from Egypt to Chartres remains obscured because of the lack of examples. Glass is a frail material, which must be pampered if it is to survive. A few literary fragments refer to windows, but no definite information is available concerning construction or materials. The most interesting description is by Prudentius in 337 A.D., who wrote about the church of Saint Paul's, beyond the walls of Rome, "In the windows are displayed glass of varied colors, as brilliant as the fields of flowers in spring."3

Before 79 A.D., in Pompeii and later in Constantinople, small sheets of clear glass were set into bronze or wooden frames. Perhaps St. Paul's windows were of a similar construction, substituting colored glass for clear.

These simple colored windows were the European predecessor of Chartres Cathedral. Eight hundred more years would be needed for the development of two additional techniques and the evolution of Gothic thought.

The first technical innovation occured sometime between the 6 th and 10th centuries. Metallurgy advanced enough to allow the production of thin strips of grooved lead and a means of soldering the lead together. The flexible lead could replace the wooden frames. The lead was strong enough to carry the weight of the glass and soft enough to mold around small and irregular pieces. The artist could now make greater use of the 
available glass and was freed from the limitation of a rigid frame. Designing with squares gave way to graceful curves and circles.

The second technical innovation was a way to permanently adhere paint onto glass. The writings of Saint Ludger (d. 809 A.D.) state that glass windows were not only composed of pieces of different colors, but they were also ornamented with painting. 4 It is believed that this painting was done with ordinary transparent pigments. The painting could be protected by sandwiching it between two pieces of glass. It would be preserved as long as the glass remained intact.

In 979 A.D. in Limoges, France, a colony of Venetian glassworkers are accredited with inventing grisaille. 5 Grisaille (from the French word "grisailler," to paint grey), originally referred to a method of permanently painting on glass. ${ }^{6}$ A mixture of iron or copper oxide would be combined with crushed glass and resin and brushed onto the surface of a piece of glass. By firing this at a low temperature, the resulting brownish-black enamel would adhere to the window glass. An infinite number of patterns and details could now be realized. Hands, faces, and drapery could be articulated, and the painterly quality was used to soften and control light. Calligraphy on glass added dates, the names of saints, and passages from the bible.

The technology for building stained glass windows was, coincidentally, available at the beginning of an age which needed it most. It is hard to think of Gothic man as coming out of the dark, when you consider what was involved in making a single window.

The raw materials of sand and soda and ash would be collected and fired in a furnace to temperatures in excess of $2500^{\circ} \mathrm{F}$. The furnace, 


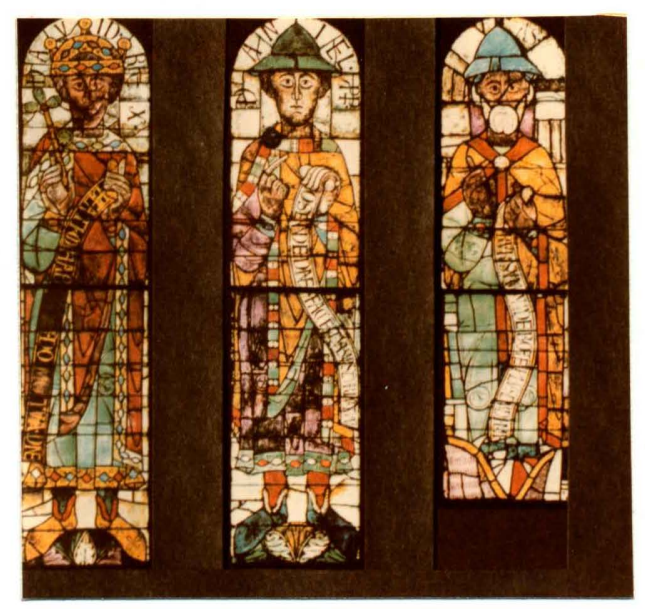

Figure 2. David, Daniel, and Jonah 1065 A.D.

fueled only by wood, would devour a small forest. Furnaces would be constantly dismantled and reestablished near another fuel supply. As the sand melts into glass, its consistency is not dependent upon heat alone, but also upon time. The amount of time glass is maintained at a specific temperature and allowed to cool affects its color and hardness. Although man had no knowledge of chemistry, he discovered how to obtain colors; blue from cobalt, violet from manganese and green from copper. The reds from copper and iron were so opaque that they were thinly coated onto layers of clear glass. Metallurgy was important for the strips of lead which held the glass together, solder which fused the lead, and the enormous iron frames, which were embedded into the masonry for supports. We should take into consideration the genius of the glassmakers, the designers, cutters, painters, and the average workers who hoisted a window a hundred feet into the air and set it snugly into place. 7 


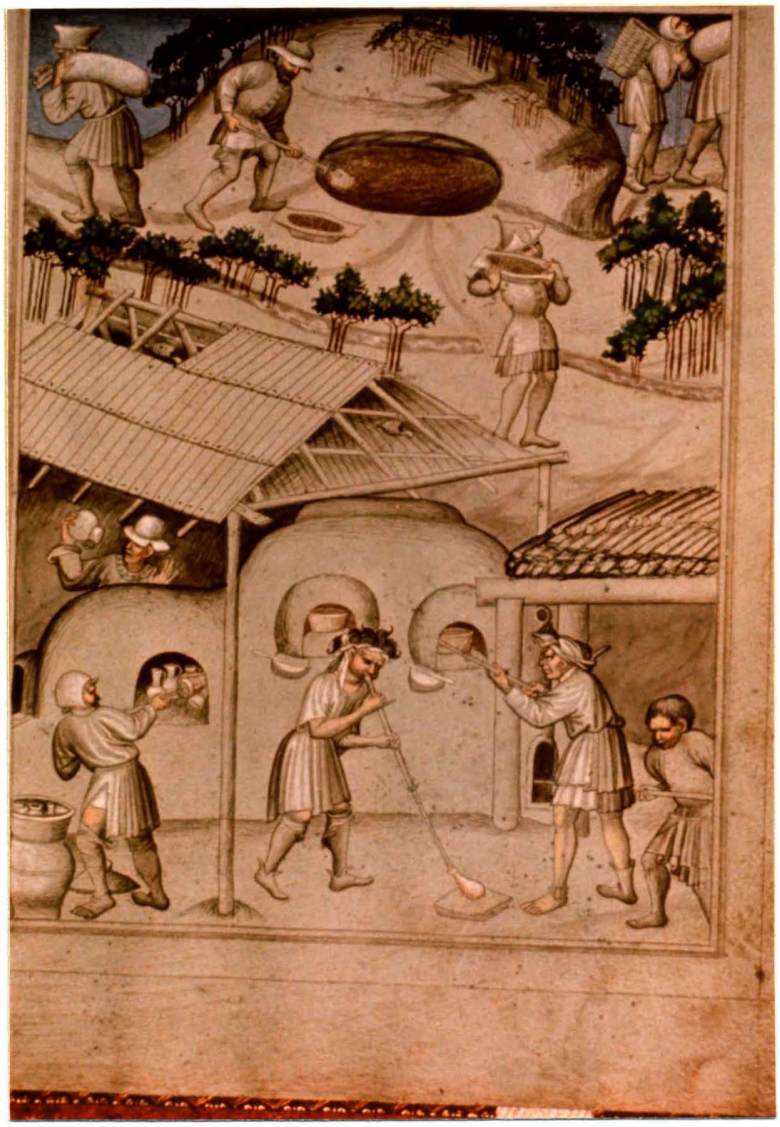

Figure 3. Bohemia glass workers 15 th century. 


\section{GOTHIC}

In 1137 A.D., Louls the VII became King of France and married Eleanor of Aquitaine. In 1140 A.D., Abbot Suger of St. Denis decided to rebulld his church and the Gothic age was visually born. 8 Suger used sumptuous, jewel-11ke stained glass to reflect the wealth of his Abbey and the magnificence of heaven. ${ }^{9}$ Each window was considered to be of enormous value, and Abbot Suger wrote of h1s protective measures,

Now, because [these windows] are very valuable on account of their wounderful execution and the profuse expenditure of painted glass and sapphire glass, we appointed an offlcial craftsman for their protection and repair . . . who would receive their allowances. . colns from the alter and flour from the common storehouse of the brethern, and who would never neglect their duty to look after these [works of art].10

The architecture of the Abbey and of all the following structures quite literally supported the windows, and stained glass as a major art form was totally dependent upon architecture. Gothic man used his powers of reason to support falth, and he used materials to reflect the immaterial. He buflt a structure of stone to validate miracles and bridge the gap between the natural and the supernatural. Architecture became a conception of space, and man worked with volds and infinity. Through his reasoning mind, he logically designed and constructed a building in which space was no longer rational. This acceptance of unlimited space, submerged the self into suggested infinity. Through stone and glass, man could have a peek at God. On the following page is a quote by Abbot Suger of Sa1nt Denis. 11 
Tunev the house of God, many colored as the radiance of precious jewels, called me from the cares of this world, then holy medication led my thoughes of prety, exhaulting my soul from the material to the immaterial, and I seem to find myself, as it were, in some strange parc of the universe which was neuther wholly of the baseness of the earth, nor wholly of the serenty of heaven, but by the grace of God I seemed lifeed in a mystic manner from this lower coward the upper sphere. 
Twelf th century Rurope was not totally commltted to bullding cathedrals and making stalned glass. In 1134 A.D., the strict order of Clsterclans forbade the use of colored glass or crosses or figures. This prohibition did allow grisallle, which refers to a type of window, usually monochromatic and of ten decorative, using intricate floral or geometric patterns. These windows reflect a belief in a simpler, less complicated 11fe, that rejects wealth and appearances. There are few surviving examples of grisaille, perhaps they are not as cherished.

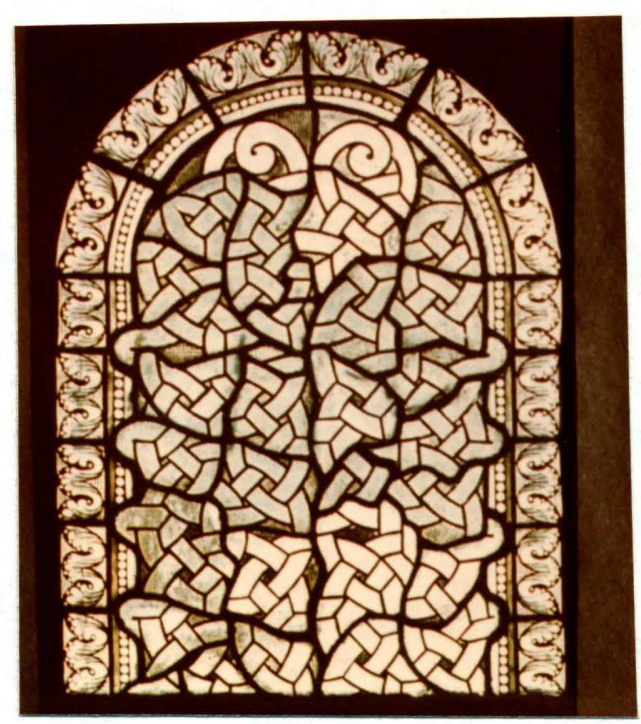

F1gure 4. Ornamental grisa11le first half of 13 th century.

St. Bernard of Clairvaux was one of the most influential churchmen of the twelfth century, and he wrote,

The church is resplendent in her walls, beggarly in her poor; she clothes her stones in gold, and leaves her sons naked; the rich man's eye is fed at the expense of the indigent. The curlous find their delight here, yet the needy find no relief. Do we not revere at least the Images of the Salnts, which swarm even in the inlaid pavement whereon we tread? Men spit oftentimes in the Angel's face...12 
The dynamic tenstons between st. Bernard's belief a and those of Abbot Suger were character1st1c of the lioth1c age. Although Bernard and Suger represented extreme points of view, both men were friends and each was searching for God.

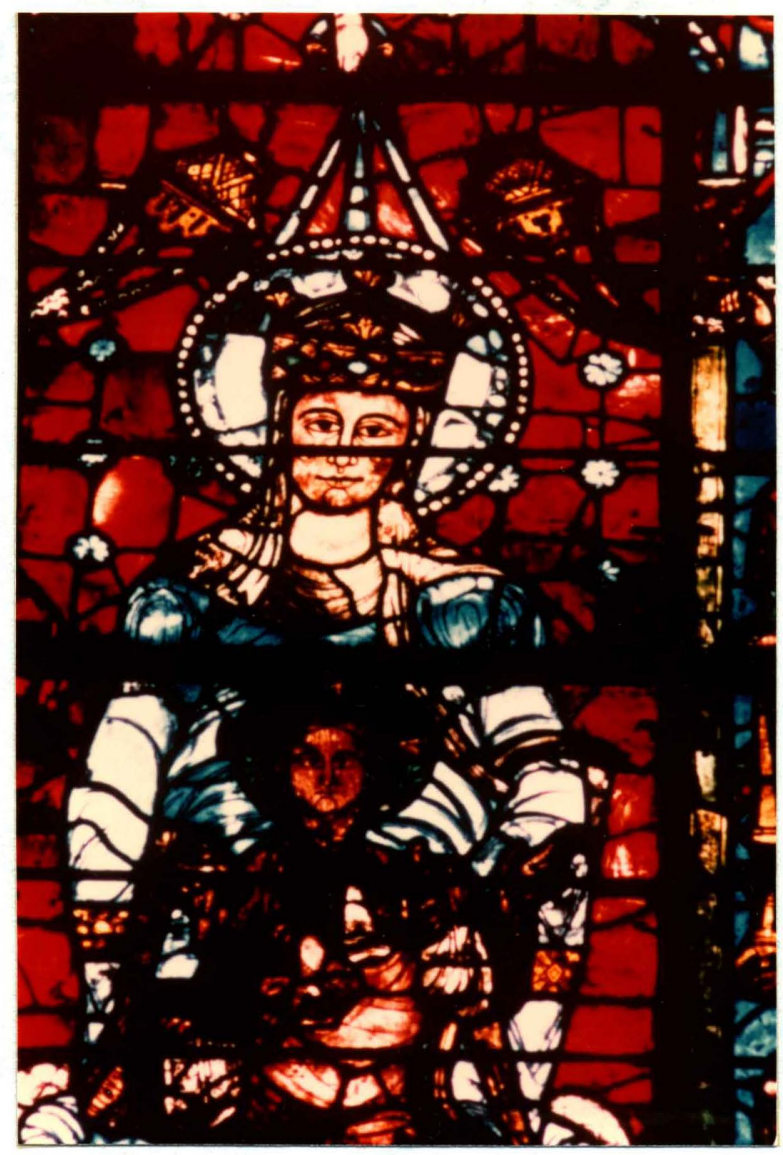

Figure 5. Deta1l, Virgin and Ch1ld center section about 1145 A.D.

Abbot Hamon visited Chartres when it was under construction, and he wrote to h1s Brothers in Normandy. On the following page is his description. 13 
Who has ever heard tell, in times past, that powerful princes of the world, that men brought up in honor and wealth, that nobles, men and women, have bent their proud and haughty necks to the harness of carts, and that like beasts of burden, they have dragged to the abode of Christ these wagons, loaded with wines, grains, oil, stone and wood, and all that is necessary for the wants of life, or for the construction of the church, they arrange the wagons about ic like a spiritual camp, and during the whole night they celebrate the watch by hymns and canticles. On each wagon they light tapers and lamps; they place there the infirm and sick, and bring them the preciousielics of the saints for their relief- 
Economics alone cannot account for the tremendous energy generated in the twelfth century when Paris was the intellectual capital of the Western World. The Ile de France, a flexible area encircling Paris, was to create eighty cathedrals and five hundred churches within a single century. With the limited technology and crude tools that were avallable, this buflding fervor must be considered a miracle. 14

The designs for stained glass are simflar to those in other mediums. Early stafned glass borrowed heavily from ename1 work, and contemporary 11lumination. Later, as windows gained prestige, book 1llustrations would attempt the same results as windows by outlining the contours of figures. Mosaics, more than any other art form, are allied to stained glass, and both are intricately wedded to architecture. Mosaics were partly responsible for the seemingly instant birth of the use of windows.

Mosalcs are constructed from small cubes of ceramics and colored glass set into plaster. Their different textures and thicknesses, combined with the uneveness of the wa11, reflected 11 ght, as an almost "shimmering, moving surface."15 The small cubes reflected the light unevenly, which created a greater vibration of color. Gold leaf was of ten sandwiched between clear glass, which helped to create an unworldly atmosphere. Mosalcs of en appear to glow, as though they are their own light source. Th1s idea of a wall that gave off 1 ight was directly translated into windows. 
The stained glass windows of the Gothic replace the brightly colored wa1ls of Romanesque architecture; they are structurally and aesthetically not openings in the wall to admit light, but transparent walls. As Gothic verticalism seems to reverse the movement of gravity, so, by a similar aesthetic paradox, the stained-glass window seemingly denies the impenetrable nature of matter, receiving its visual existence from an energy that transcends it. Light, which is ordinarily concealed by matter, appears as the active principle; and matter is aesthetically real only insofar as it partakes of, and is defined by, the luminious quality of light.16

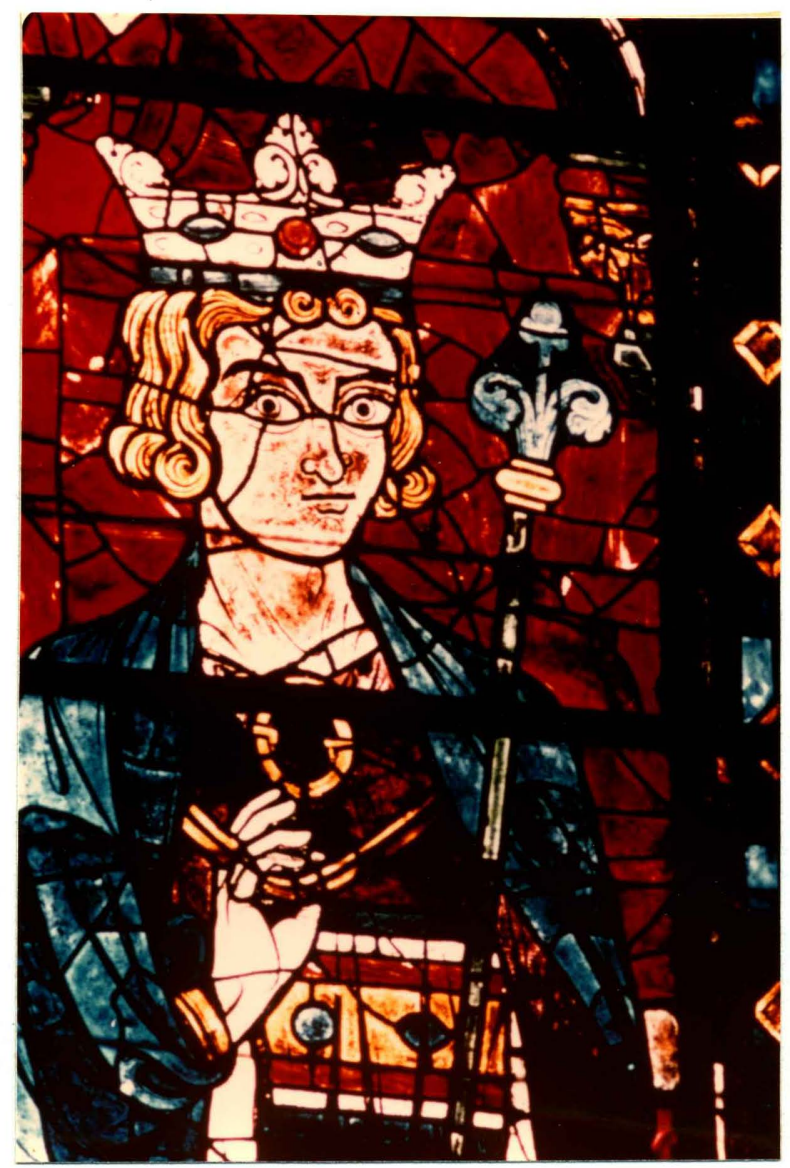

Figure 6. Detail, Solomon before 1240 A.D.

The spirit of Gothic man, his thoughts, and visions, were perfectly expressed through the transcendental quality of stained glass. Man had 
just rediscovered the world on the basis of his senses, primarily that of sight. Visions and trances were experienced by God's elite, and vision inducing properties are inherent in intense light. Sunlight, transmitted through colored glass, is unparalleled in its brilliance and the inside of the cathedral became transformed into a mosaic of saturated color, mysterious and etherealized. Not only the subjects of the windows, but the windows themselves, turned the light of day into Christian use.

In both philosophy and theology God was Light. Robert Grosseteste was a medieval scholar who formed a complex philosophy conceiving of God as Light: ". . . and the whole material universe as a brilliant sphere radiating from a central nucleus into the three divisions of space. All human knowledge sprang from the spiritual effluence of this primal, uncreated Light."17

In theology it would be difficult to find a theme more stongly emphasized by scripture than God is Light. The major ideas offered by Christianity were those of enlightenment and transcendency. At the close of every Mass, the priest would read from St. John I, 4, 5 and 9: "In him was 1ife; and the life was the light of man. And the light shieneth in the darkness . . That was the true Light, which lighteth every man, that cometh into the world." 


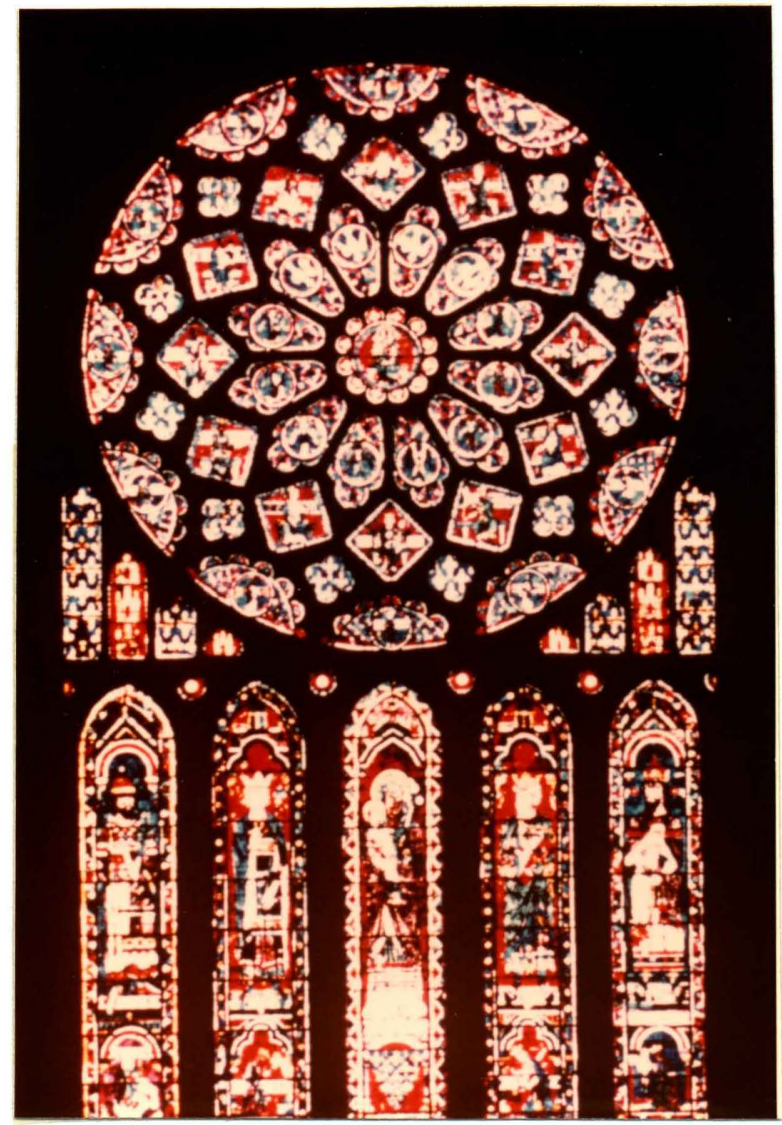

Figure 7. Rose window before 1240 A.D.

On the following page is an interpretation of an architectural structure as a reflection of God. 18 Gothic symbolism transformed all of nature into a lesson and proof of His existence. 
The are of the glass-worker was broughe to perfection in the large rose windows which in the-mid thireenth century were sec up over the new transepes. These elaborare compositions signify at once the cycles of the cosmos, the merging of cime inco Evernicy, and a mystery of a God who is Lighe, of chrise the Sun. Circular, they demonseraze, in a whirl of rocacing spheres, the idencity of Aristorle's concentric universe with the centrifugal effusion described by Rober Grosseceste. Che rose is atso a symbol of love; it represents the fiery core of that divine love in which all human loves are consumed. And we also see in ic a figuration of the labyrinth through which profane love gropes its way towards that sacred love which is its goxl. 
SECTION TWO

A

SELF-GUIDED

TOUR

OF

STAINED GLASS

IN

WEST PORTLAND 


\section{INTRODUCTION}

It would be a delight to go back in time and stroll through the French cathedrals. Perhaps sometime we will. But, we should not feel dismayed at being where we are, for everywhere has something to offer and Portland has a few gems of her own.

There are a few places where you need not look for windows. For example, government buildings, which are generally devoid of art. Industrial and commercial architecture, which has bent us into cubes, does not permit the delicacy of colored light. The Museum of Art has not one stained glass window in its collection. Private homes which once catered to Victorian taste for windows could be a good source, except that they are private.

Any study of stained glass in Portland must be done through the churches, which collectively have the greatest number of windows, all of which are in their original architectural setting. The churches are fulfilling their traditional role of being the patrons and protectors of stained glass. The churches are providing the setting needed for the initial enjoyment of windows. For part of the magic is to be completely surrounded by colored light so that you are on the inside of it.

This self-guided tour was developed for individual speed and personal leisure. When planning a walking tour, distance must be taken into consideration. West Portland has the largest number of older 
churches within a concentrated area. Another consideration is access. Some of the windows that you will walk past can only be seen on Sundays. All of the selected churches have educational wings, and, with permission, you can view the windows any weekday.

It is not the function of the tour to explain the process of window making. The technical aspects of design and construction cannot be discussed in so short a paper. Indeed, it is a life's study. Nor will the emphasis be on the history of the buildings or windows, although the artist, when known, will be discussed.

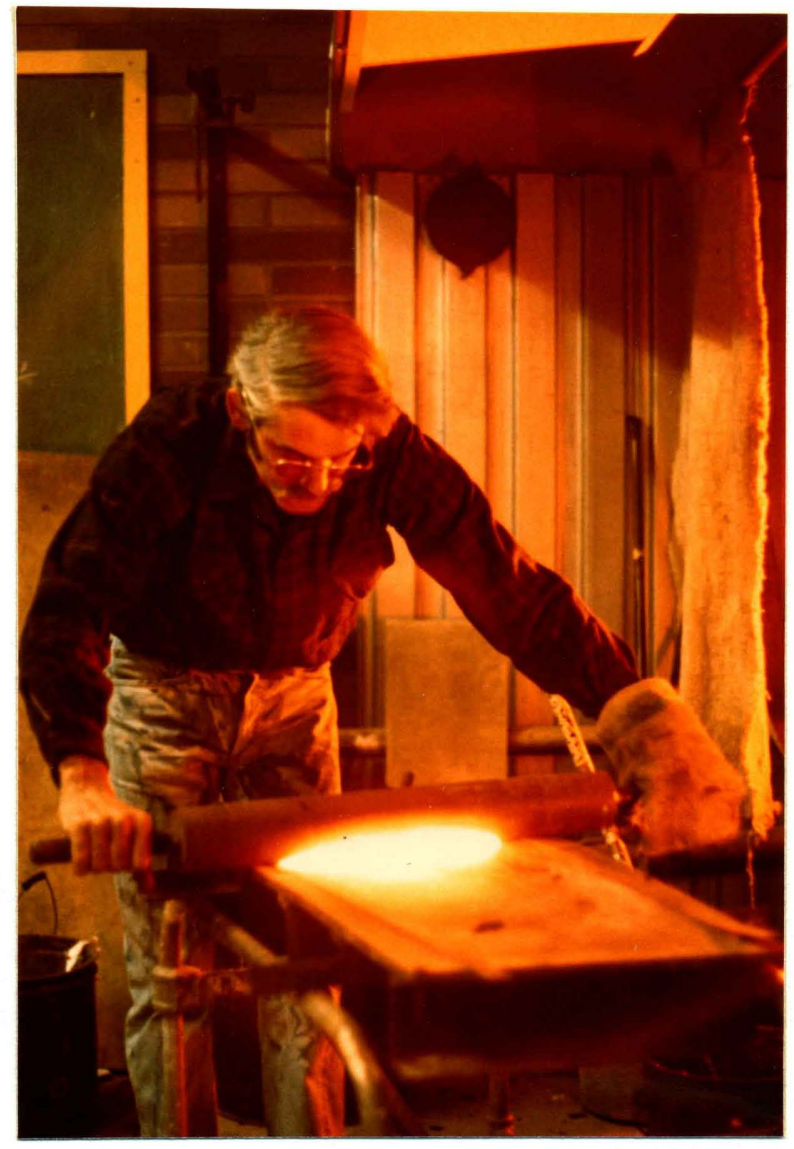

Figure 8. Hand rolling glass in Portland. 
The purpose of the tour is very simple. It is to provide a basic beginning for the enjoyment of stained glass in Portland and a reference point for further study.

To view a window of stained glass is to borrow the sun. The sun comes and goes in its own Time as if to remind us that there is still a natural and unchangeable Order. Light and Dark.

Work and Rest. Stained glass windows symbolize that flow. They recall beginnings. 1 


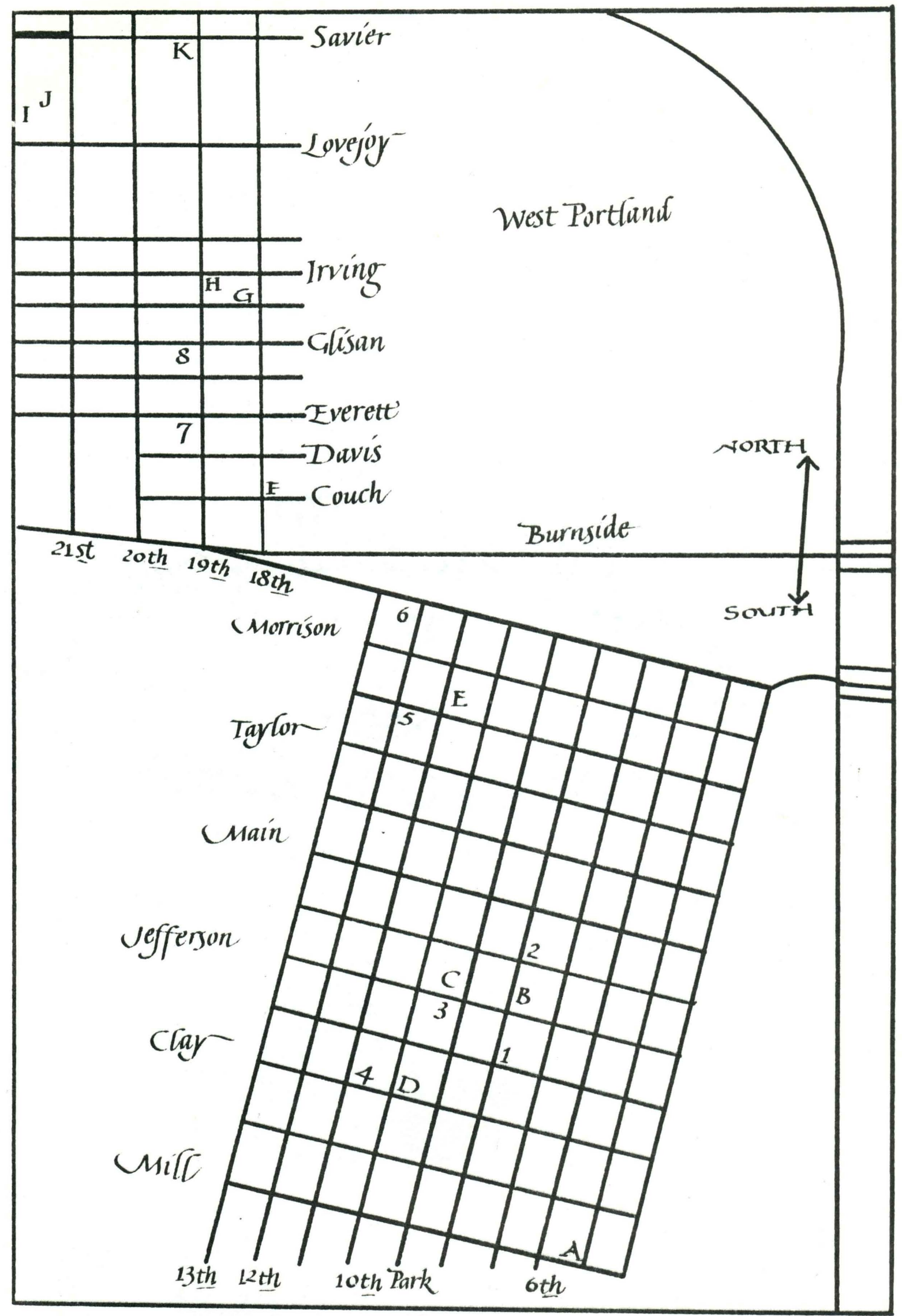


UA,LKIXGTOUR

1 First Christian

2 First Congregational

3 Saint James Lutheran.

4 old Church

$\checkmark$ First Baptist

6 First Presbyterian

7 'Trinity' Episcopal

8 Temple Reth Israel

PLACE $\cong$ ONTEREST

A St.Marysi Academy

B Oreoon Historical Society

C Eortland Art Museum.

D 'First Evangelical.

E Multnomah Cunty Library

F st Mary's

G Northwest Conservative Raptist

$\mathrm{H}$ 'Evanselical Jutheran

I Chapel of the Cood Samarican

J St Mark's

K St Patrick's

Not SHOWN ON MAp/Riverview Abbey Tiylery Feriy Rd, - Hubers Rotaurant -

Picneer Bldg, st - 11 ichaels - 4 this - Mill. 


\section{Fint Christian}

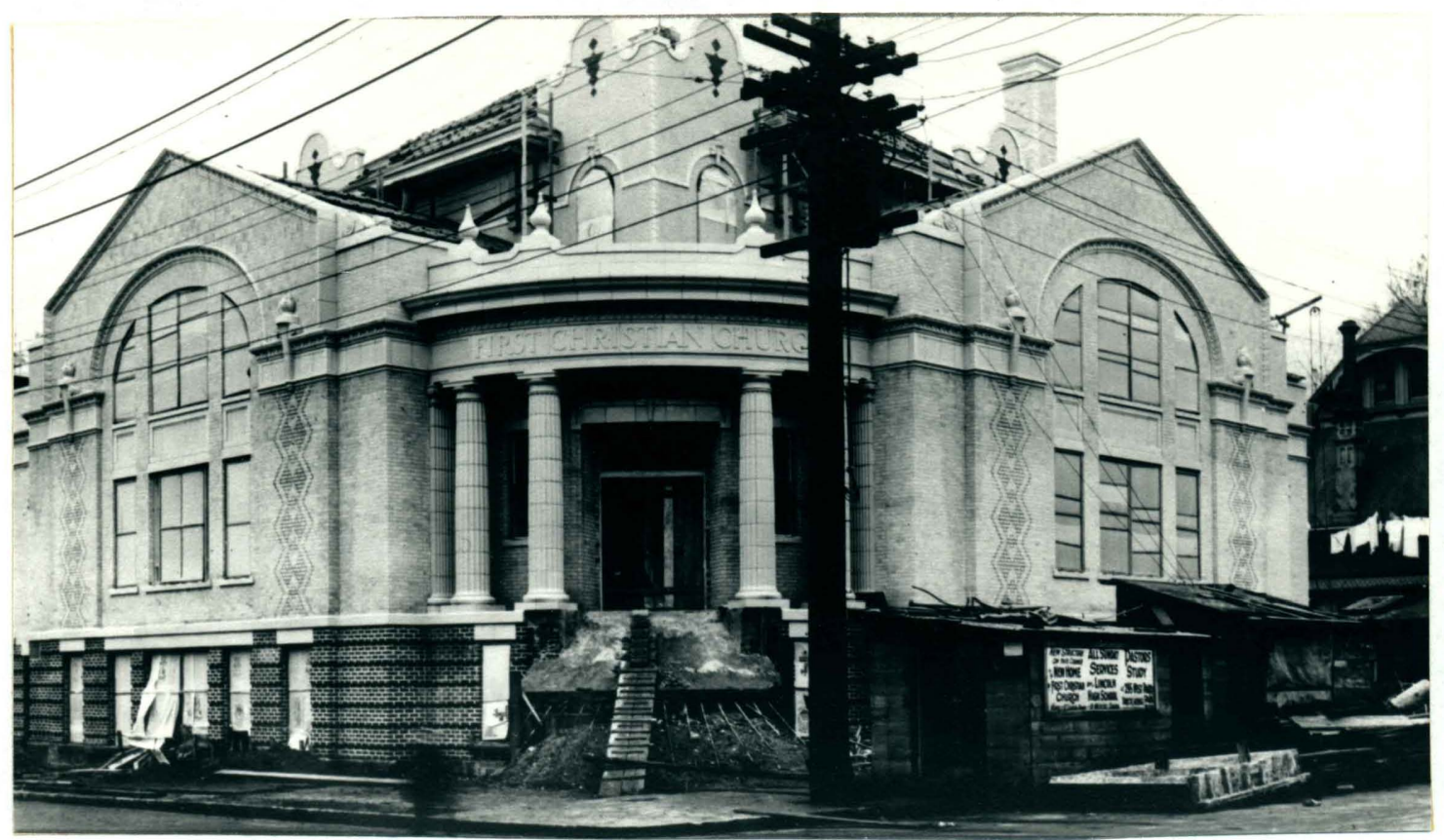

Figure 9. Exterior.

The First Christian Church was completed in 1923, and the windows were installed soon after. From the outside, the bullding appears to have a coherent and large interfor. Yet through remodeling and the addition of an education bullding, the interfor space has been divided into smal1 rooms. This church contains an impressive number of windows, yet they are sometimes in obscure places. Mafor figurative windows are found in the basement and the kitchen. Many of the smaller windows in stairwe1ls and passageways are themes not usually expressed in stained glass. For example, the small window on the second floor, above the main entrance, contains a campfire, with the inscription "Be Prepared." In the sanctuary, above the altar, to the south, is a large window of the dome of the Capitol, and the inscription "Washington D.C." The windows to the left and right of the altar are victims of remodeling. They are 
artificially lighted.

A11 of the windows were made by Povey Brothers Studios. ${ }^{2}$ David L. Povey designed the major windows, yet there is so much individuality in some of the smaller windows that they may have been designed by a studio artist. A commission this large could not have been done by one person in a short period of time.

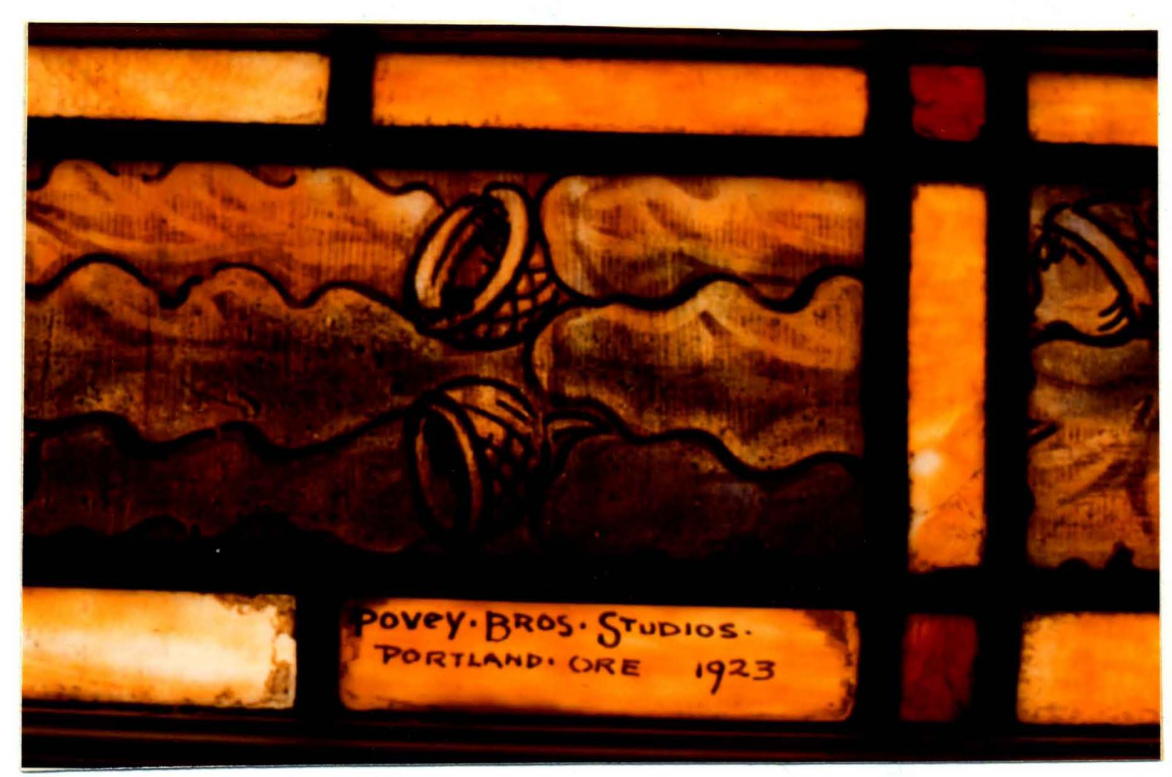

Figure 10. Detail, Povey signature.

The most interesting comparison is the large west sanctuary window and the window in the choir room, to the south of the sanctuary. These windows, which were done within the same year and produced in the same studio, show a very different treatment of glass.

The sanctuary window, which is signed in the lower right hand corner, relies on painting on the glass. ${ }^{3}$ The feeling is that you are looking at a painting that has been lighted from behind. The emphasis of 
the window is on its didactic quality, and the viewer becomes involved with the story of the window. The glass transmits an even intensity of light, and opalescent, or milky white glass, is not used. The window in the choir room is different in effect. The grape leaves are separate pieces of glass, which imitate the quality of natural leaves. The oak leaves in the sanctuary window are painted onto a larger piece of glass. The robe in the choir room is cut from a piece called "drapery glass." This white glass was folded when it was made to imitate cloth. The sanctuary window drapery is heavily painted on a flat piece of clear glass. The choir room window uses different kinds of glass to transmit different intensities of light. The brightness of the robe stands out against its dark background. 
- First Congregational.

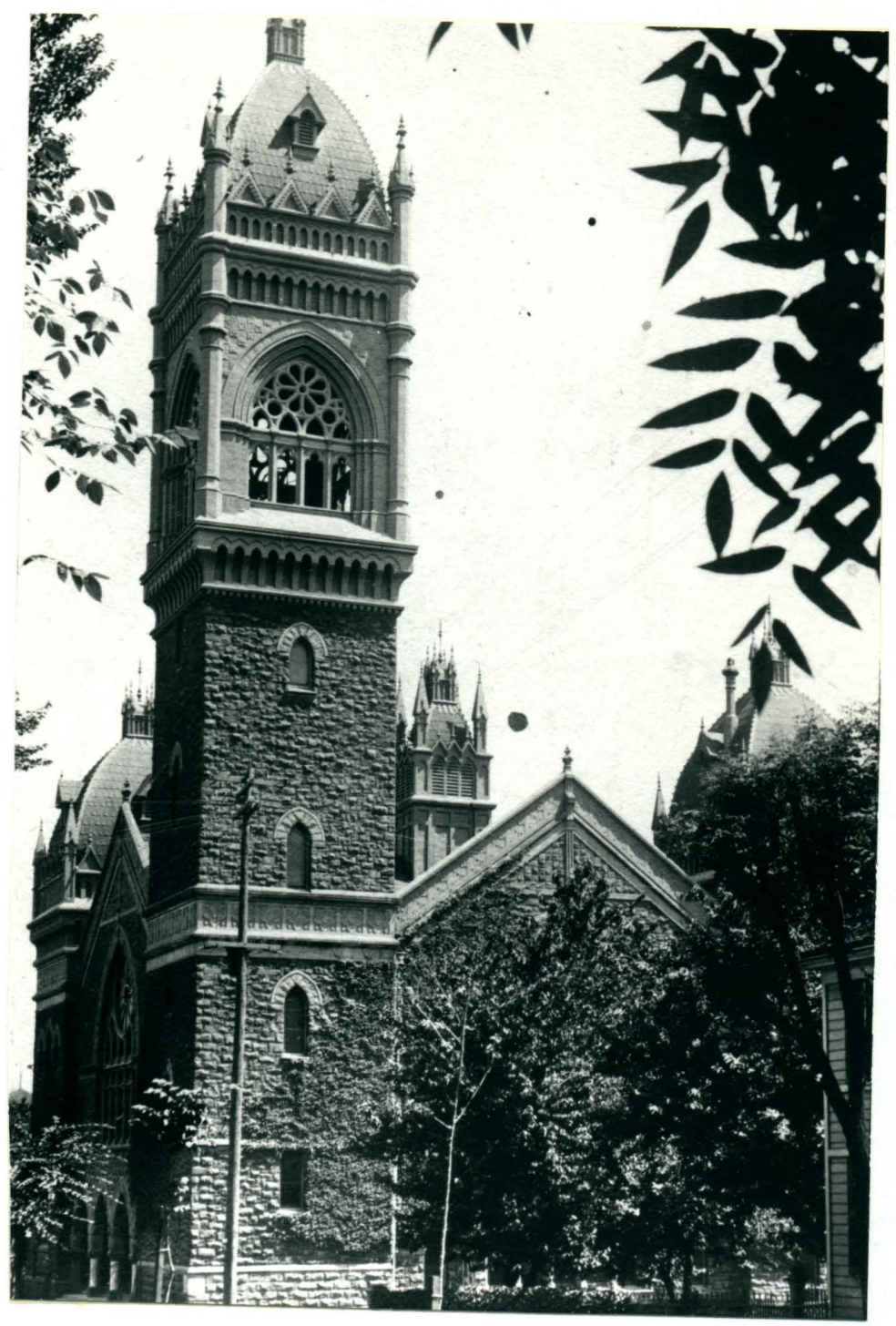

Figure 11. Exterior 
The building was completed in 1894, and the windows date from 1906 to $1959 .{ }^{4}$ In the sanctuary an amazing amount of wall space is given to windows. At first this is not noticeable because of the balcony which blocks a great deal of light. The large window area is made possible by the use of tracery, which is a wooden or masonry support. Tracery is often used to further divide a massive area into more irregular or complex shapes which can be seen in the three large circular windows.

A11 of the windows in the sanctuary were made by Povey Brothers Studio and dedicated from 1906 to 1910. The north window is composed primarily of yellows and clear glass, probably designed for maximum entrance of light. The theme is more symbolic, which avoids figures, and thus reduces the need for painting. The lower panel is monochromatic, with the single exception of a torquoise-blue cross.

The west and south circular windows are rich in the details of their borders. The west border shows three views of a lily, intertwined in a continuous motif. The south border shows grapes, leaves, and vines in a nearly perfect combination of glass, paint, and design. The smaller windows surrounding all three circular ones are the same in design. They differ only in detail and color.

Nearly fifty years separates the Povey windows from Albert Gerlach's north vestibule windows, dedicated in $1959 .^{5}$ The wooden tracery and use of a figurative circle reflects the designs of the sanctuary. The clear glass permits light for the practical consideration of a dark corner. The figurative medallion was adapted from a painting by Murillo. This tradition of translating paintings into windows is commented on by Mr. Gerlach, 
It $1 \mathrm{~s}$ only too true that the popular 1dea today is a 'p1cture' in glass. But what might be a beautiful picture on canvas cannot be rendered successfully in glass. Symbolic representation is preferable to pictorlal. Symbols are preclous because they convey a wealth of meaning in compact form and enable us to express what would otherwlse be too great for us. 6

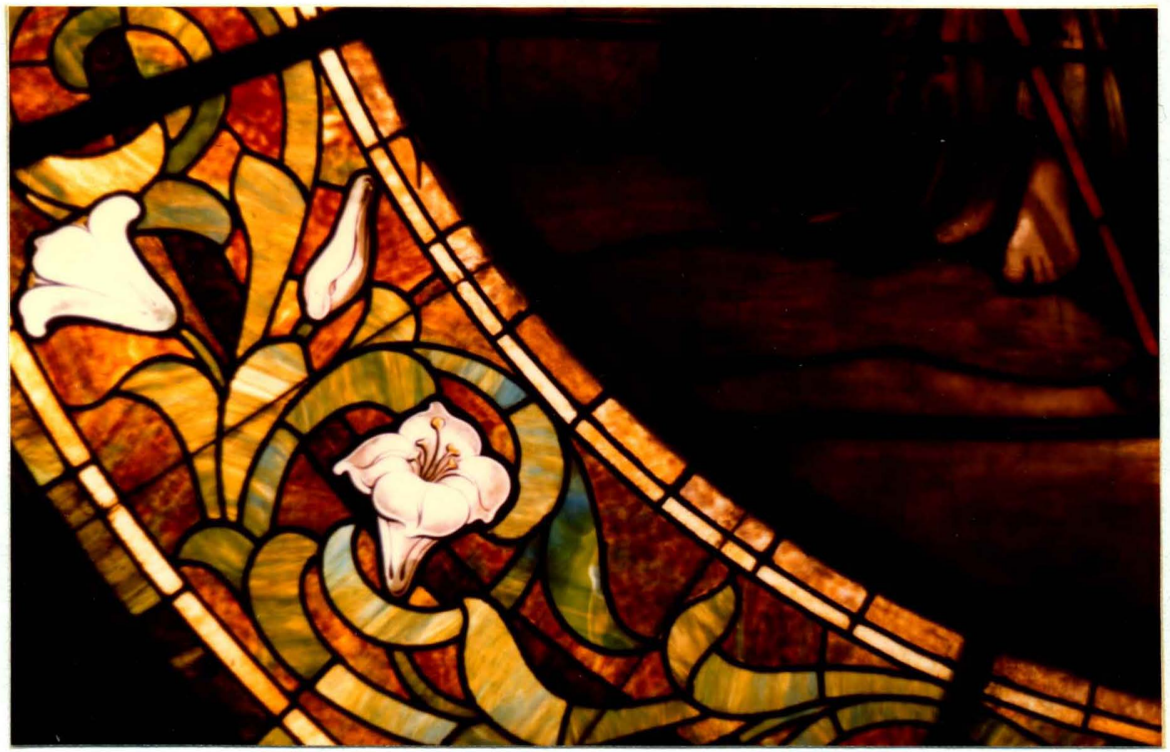

Flgure 12. Deta11, west circular. 

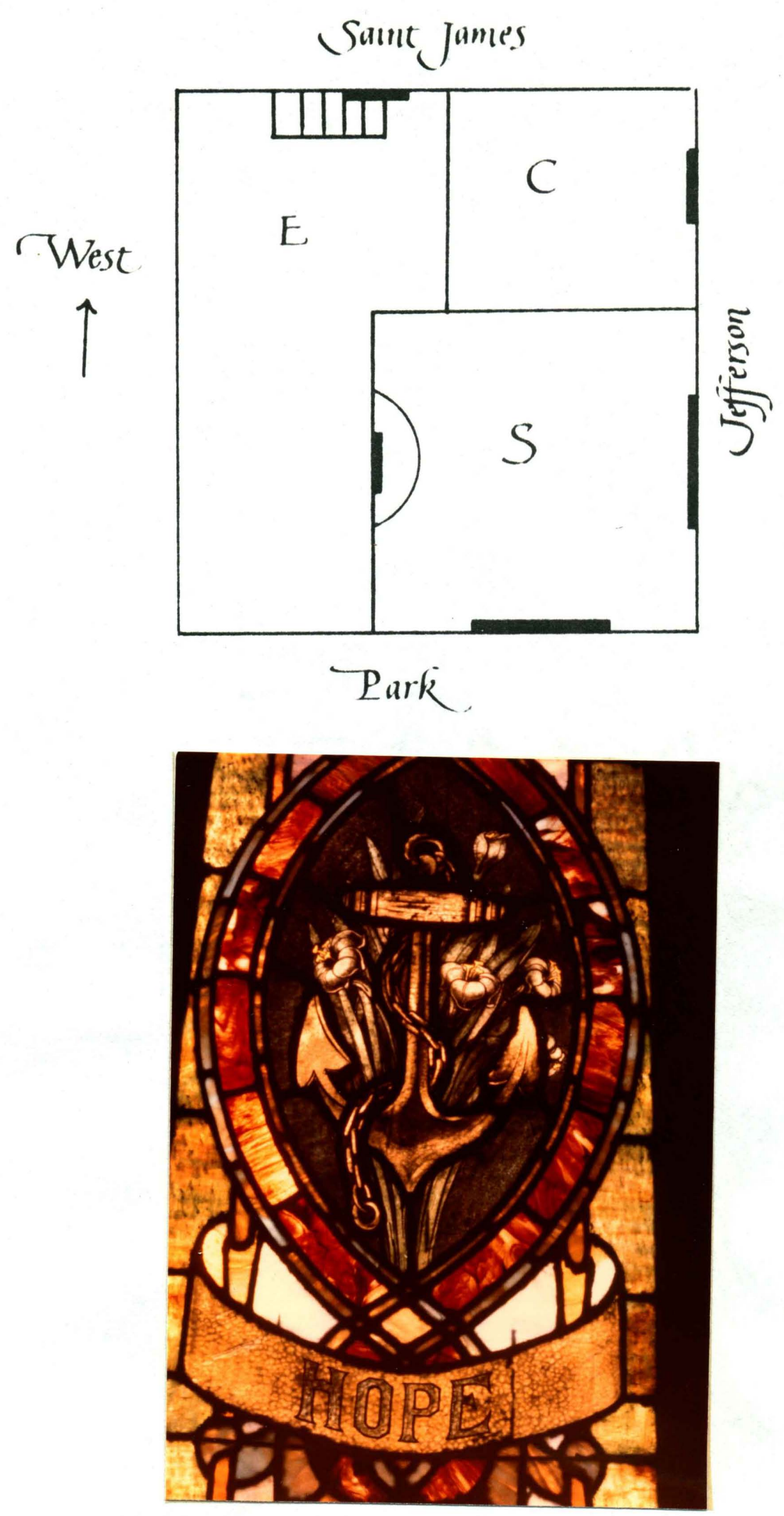

Figure 13. Detail. North 
The altar window and the large east and west windows in the sanctuary (S) were made by Povey Brothers Studio and dedicated in 1906. They are contemporary with those in the sanctuary of the First Congregational. The treatment of the intertwining lilies above the altar in St. James is similar to the border of the west circular window in the Congregational. The St. James altar window was not originally intended to be lit by electricity, but the addition of an educational wing blocked the original sunlight.

One of the problems in window making is to create a coherent light. A11 of the lower panels in the sanctuary use the same design, with changes in the center section only. The predominant glass used is a white opa1escent, which transmits a soft, clear light. By using the same proportions of colored glass in each window, a unified interior light is created. Mr. Bert Willemse of Scappoose designed and made these lower panels, as well as the windows in the stairway in the back of the educational wing (E). These stairway windows were completed in 1959 and reflect the contemporary idea that the windows should contain large, simple-shaped pieces of clear color.

The chapel (C) contains one of the most interesting windows in Portland. The "Mission League" window was dedicated in 1898, and there are no records or reminiscence concerning the craftsman. There is some speculation that it was imported, because of the type of lead used. Certainly imported windows were common, even at this early date, and it shows how indistinguishable the American and European designers were. Even the U.S. east and west coast designers often used the same sales catalogue. What is unique about the "Mission League" is the sense of 
color. It is essentially low-keyed color with an intense blue running through it, like a bright thread through a dark tapestry.

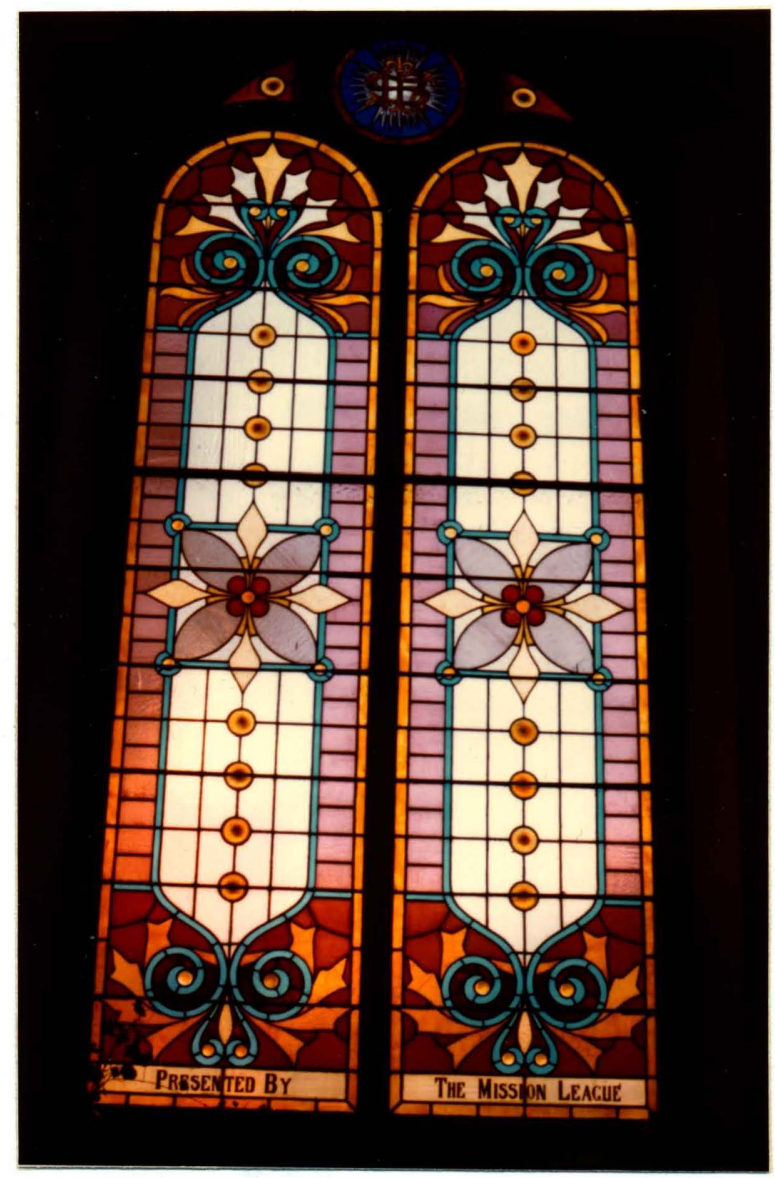

Figure 14. Mission League.

Color is emotional. You see it everywhere, all around us. Color plays an important part in the life of everyone. It changes peoples' moods and is closely interwoven in the fabric of our daily lives. In working with stained glass my selection of one piece of colored glass over another is largely emotional, and therein lies my total involvement. It is a day-to-day love affair, supremely stimulating and richly rewarding. 7 


\section{old Church}

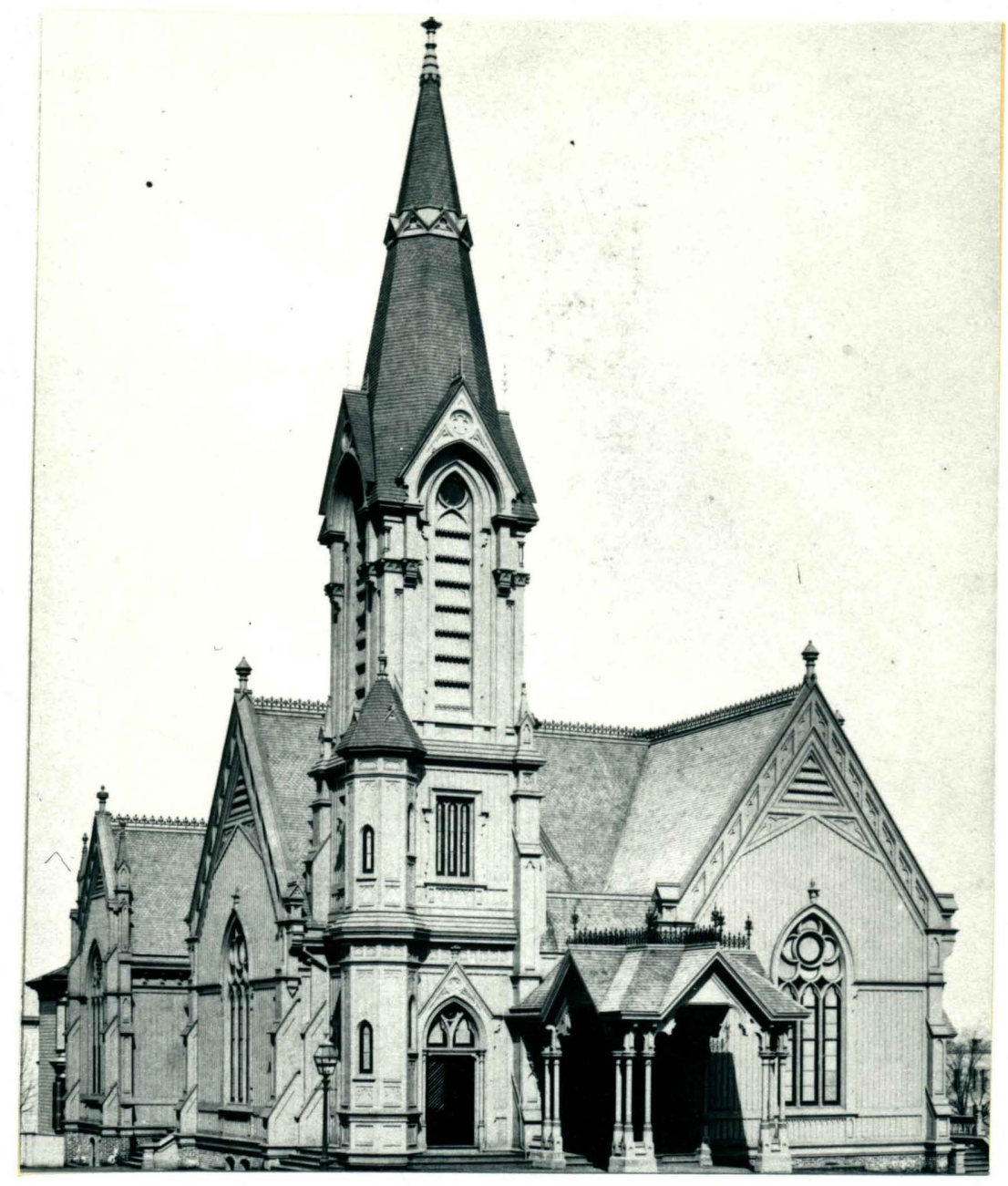

F1gure 15. Exterior.

Recently, much has been written about the old Church, and historical information is available about everything but the windows.

The major window is inscribed "Consider the Lilies." 8 This window was installed sometime before 1895. It has been rumored that it was made in Rome, but there is no evidence to prove this. Judging from the glass, there is no reason why it could not have been made in Portland. The treatment of the lilies is so simflar to David Povey's that it may have been made by his firm, although there is no documentation. 
If you examine the brownish glass surrounding the "Consider the Lilies" medallion, you will notice its irregular color. All of the glass has been darkened and pitted, mostly by the wind blowing dirt and sand against the outside. This gives the window a softer quality of light than originally intended.

The most interesting aspect of this window is the designer's use of white. The glass in this window is kept dark and subdued, with the exception of the whiteness of the flowers. There are over 160 lilies, distributed evenly over the entire surface. They form pinholes of bright light on a field of darkness. The designer also chose very small pieces of glass, which break up the light, and contribute to the shimmering moving surface.

To the north side of the altar is a small window that could easily be adapted for domestic use. The designer used variations of the same color, cut into flowing curves, and accented by yellow and one small green. The designer also used jewels as accents and areas of interest.

Jewels are made by pressing hot glass into iron molds. They may be irregular in shape, or faceted, are often three quarters of an inch thick. The effect is often the same as a cut diamond. They absorb more light because of their relative thickness, and scatter light because of their multiple surfaces. Jewels are used in windows to concentrate and intensify light. They are accents, just as a spot of red accents a sea of blue.

The large west window in the sanctuary is original and is a good example of what many windows replaced. Often a congregation, after meeting the expense of the building, could not afford to purchase stained 
glass. Temporary windows would be installed, to be replaced as funds were available. The temporary windows in Kinsman Hall are still intact, and are a delight. This church must have been plagued with debts to only instal1 two windows since 1885 .

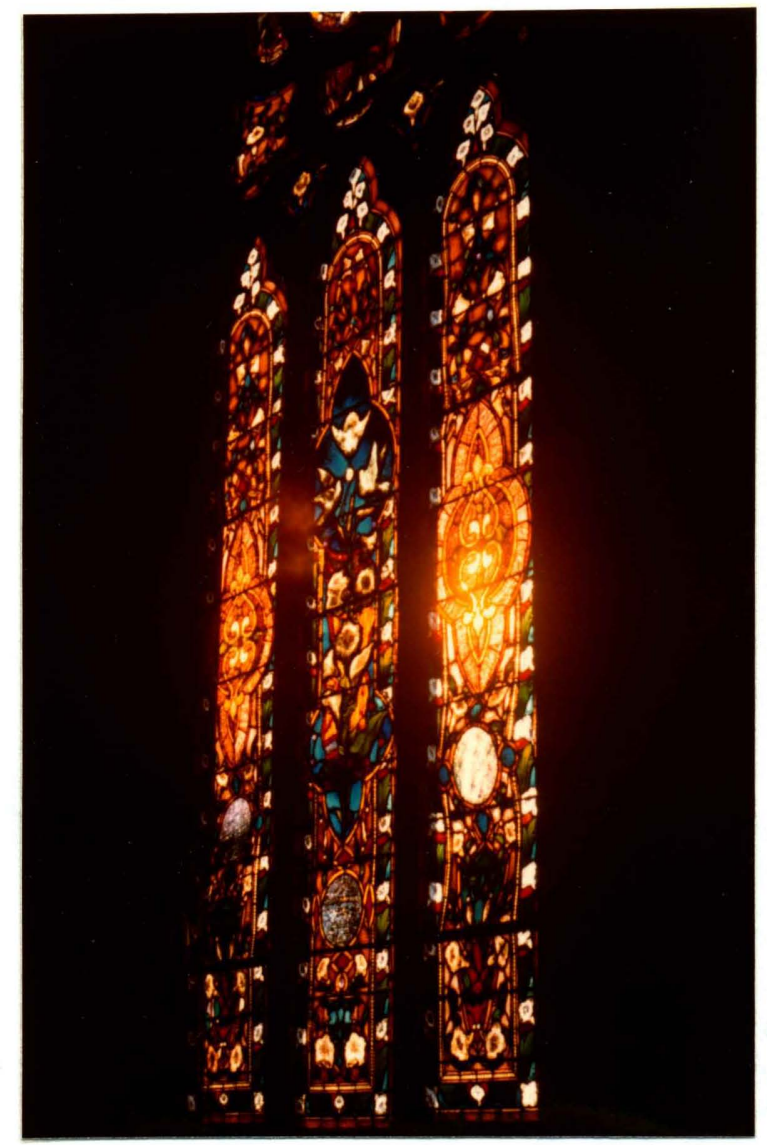

Figure 16. Consider the Lilies. 


\section{Fint Baptist}

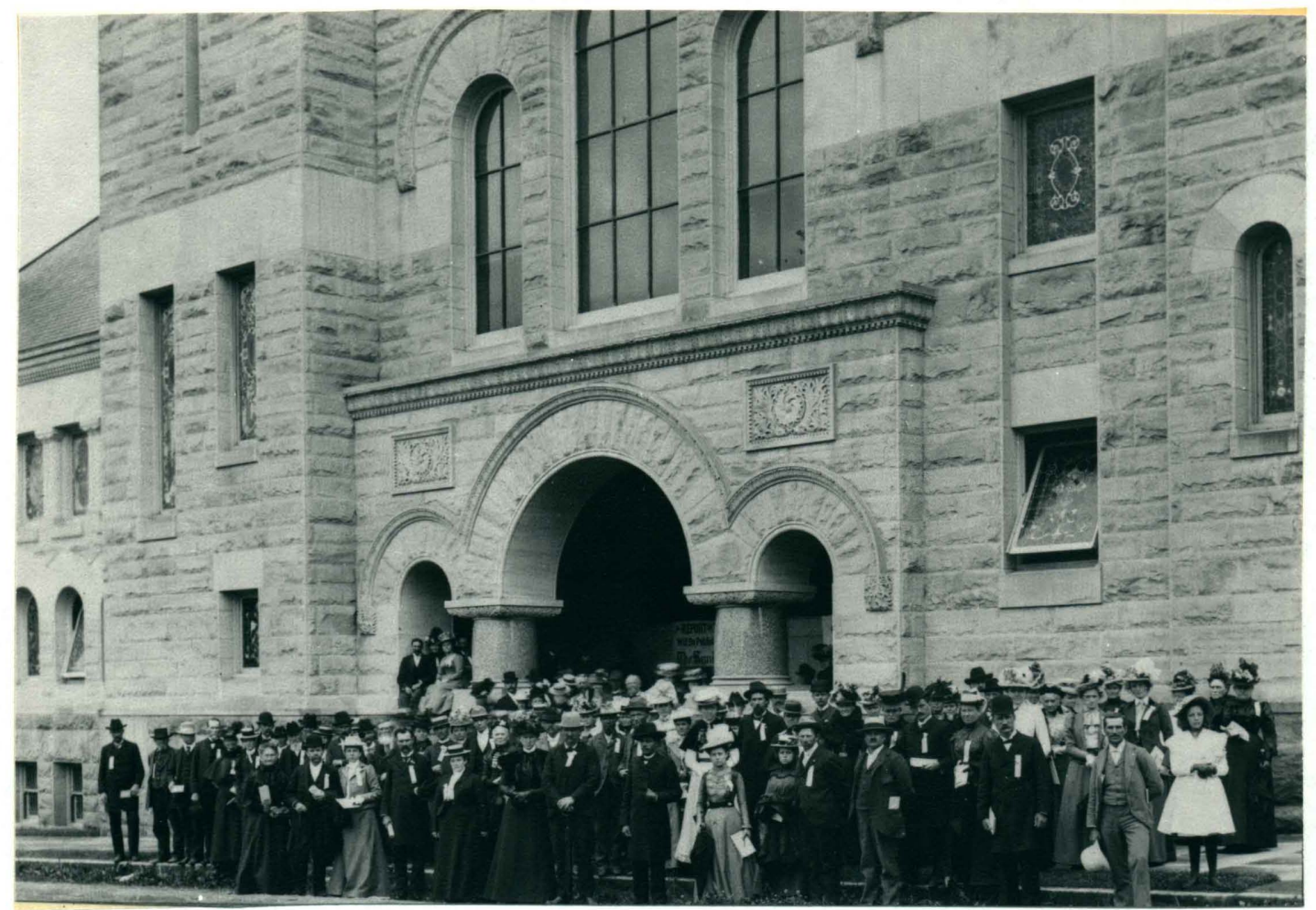

F1gure 17. Exterior.

The First Baptist was dedicated in 1894, and within a short time, a11 of the smaller windows were completed by Povey Brothers Studio. In some ways, these minor windows form an interesting collection of what could be considered Victorian stained glass. The designs could easily have been used in private homes, reflecting the turn of the century taste for opulence.

The west window on the ground floor, in the northwest vestibule, is a good example of Povey's mastery of 1ine, use of opalescence, and preference for using jewels. 
Stained glass necessitates the use of grooved lead to hold the glass together. Traditionally, lead has been used structurally, and also as a black to divide one color from another. In this northwest window, Povey incorporates the lead as a line. There are many leads that are not structurally needed and do not necessarily divide one color from another. Instead, the lead forms a swirling, curving line which adds a dynamic movement to the design.

Povey is also a master in his use of opalescent glass. Opalescent, or flaming opal, is milky in appearance, and may be of any color. It was not used for windows until John LaFarge and Louis Tiffany started their window experiments in the 1870s. Opalescent and clear glass are not always easy to use in combination. Clear glass transmits a direct light, but opalescent diffuses and retains light and seemingly softens it. In these Baptist windows and especially in the northwest example, Povey uses opalescents as an accent, in contrast to the other glass, adding a richness of variety. 9 Povey was also fond of the use of jewels, and fills his windows with every shape and color available. Jewels reflect the feeling of abundance and are constantly surprising us in their reflection of light.

The large west window "Sermon on Mars Hill" was dedicated in 1910. This window was made by Henry Holiday in England and given by the Failing family. 10 Although Mr. Holiday never visited the church, a member of the Failing family did visit him in England, and water color sketches were exchanged as well as later correspondence. One can only imagine the difficulties in transporting so large a window.

In 1931, the north window, "Communion of the Apostles," was made by 


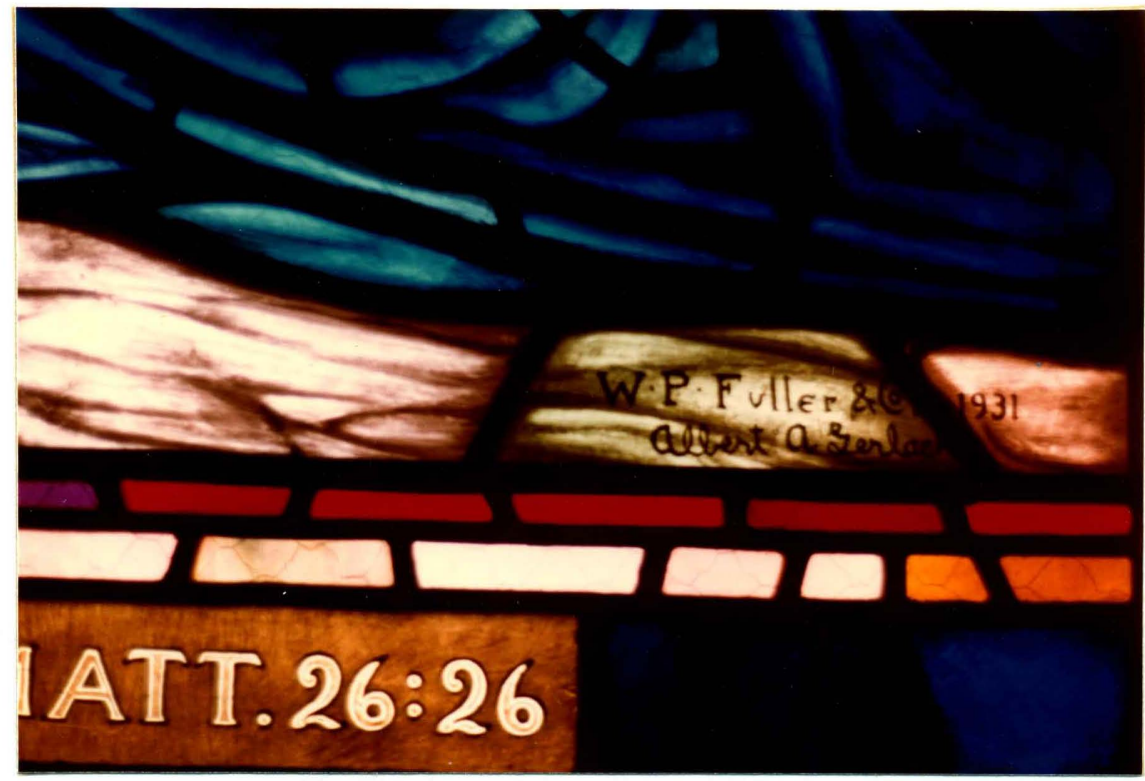

Figure 18. Detail, Gerlach signature.

W. P. Fuller and Company, under the direction of Albert Gerlach. ${ }^{11}$ The design of the central panel was adapted from a painting by Jules Delaunay (1828-1891). Line is used structurally, opalescents and jewels are omitted. The central panel relies on painting on the glass. The side panels appear to be decorative, but symbols are subtly worked into the design. Christian iconography is almost a language in itself, where each sign and symbol represent a saint or martyr or miracle. Many symbols are actually older than Christianity and were adapted to meet Christian needs. Each panel contains six crests, and each crest represents an apostle. On the left hand panel is a crest with keys, which stands for Peter, cross and spear for Philip, eagle for John, staff and script for James, square and spear for Thomas, and cross for Andrew. 
Fint Presbyterian

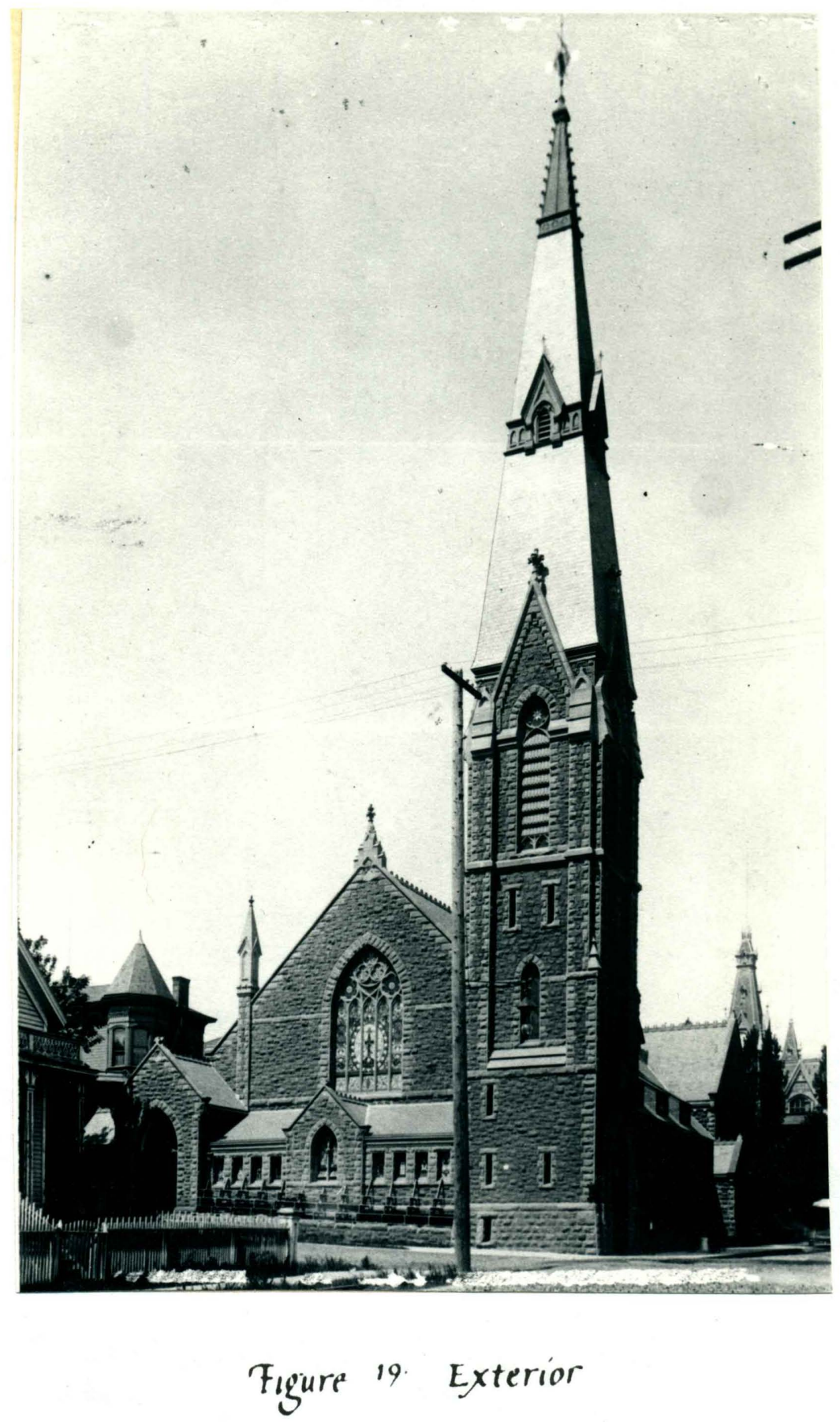


The First Presbyterian 18 Portland's finest example of a V1ctorian Gothic bullding. The tower is dated 1887, the main sanctuary was completed in 1890, and by 1899 the church was dedicated free from debt. The spire 18 copper and reaches 185 feet into the air. Pinnacles, dormers, massive stone arches and a belfry decorate the exterfor. The interfor is magnificent in deta1l, and elaborately hand carved by Nicholas Strahan. All of the windows were made by Povey Brothers Studio.

The oldest part of the church is the chapel. A large original south window has been covered by remodeling, but a north window remains in what is now the choir room. The subject of this window is "Consider the L111es." The history of this church indicates that because of overcrowding or conflict, a part of the congregation left and bullt the present 01d Church. The subject of the major 01d Church window is also "Consider the L111es," and both windows are contemporaries.

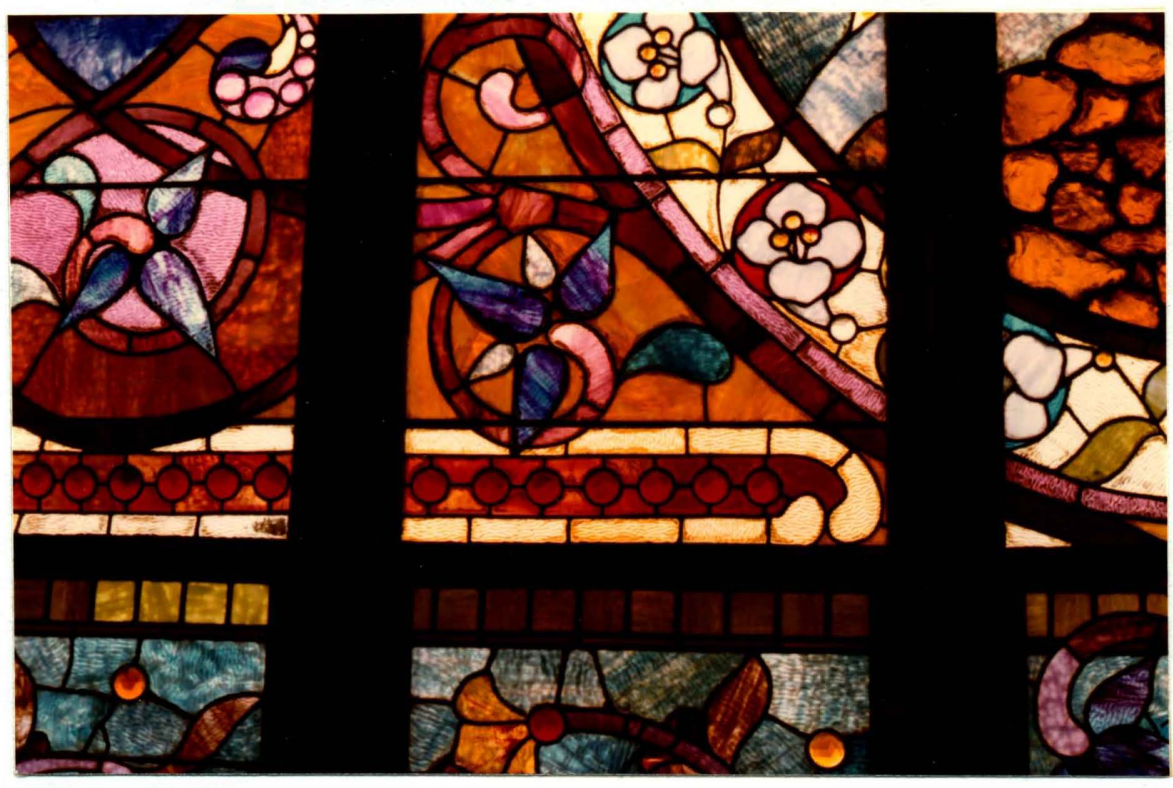

F1gure 20. Deta11, east. 
In the first six churches on the tour, the lily has always been present. In borders, and as a major motif, the lily is shown in three different stages of growth: closed, a side view, and frontally in full bloom. In the Presbyterian Church, the lily is in the choir window, bordering the east medallion and above the east doorways. Stylistically, the lily motif may indicate that it was the work of David Povey, but there is no documentary evidence.

The east window in the sanctuary is a profusion of jewels, activated by swirling rhythms of glass and lead. The cross is very unusual, as it is composed not of flat glass, but large chunks of chipped and fractured glass. The irregularity of the cross glass and its massiveness is reminiscent of natural rocks. While Povey was experimenting with these chunks, Louis Tiffany was picking up translucent quartz pebbles on the beach at Montauk and incorporating them into his windows. 12

The sanctuary surrounds you with the warmth of wood, the color of red brown, and the intricacy of decoration. The windows designed for this interior display careful use of light colors, to transmit the maximum amount of sunlight. The overall design is the same, and windows are in pairs. Lighter glass is used at the tops, gradually becoming darker at the bottom. The colors are carefully chosen to complement the interior wood, and limited to shades of amber, blue, and violets.

The small windows in the vestibule are a designer's delight. Whimsical and flowing, the colors retain and transmit the sun. The jewels throw out small spotlights of sun, everchanging with the day. 


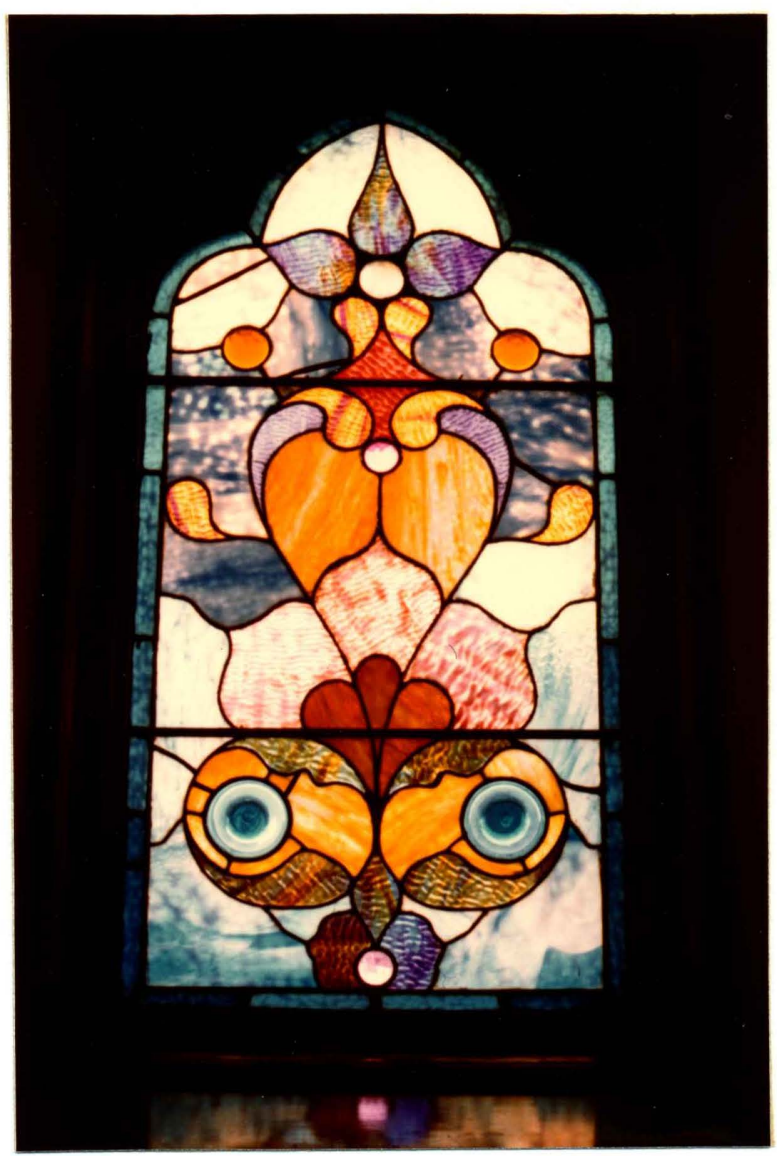

Figure 21. Vestibule. 


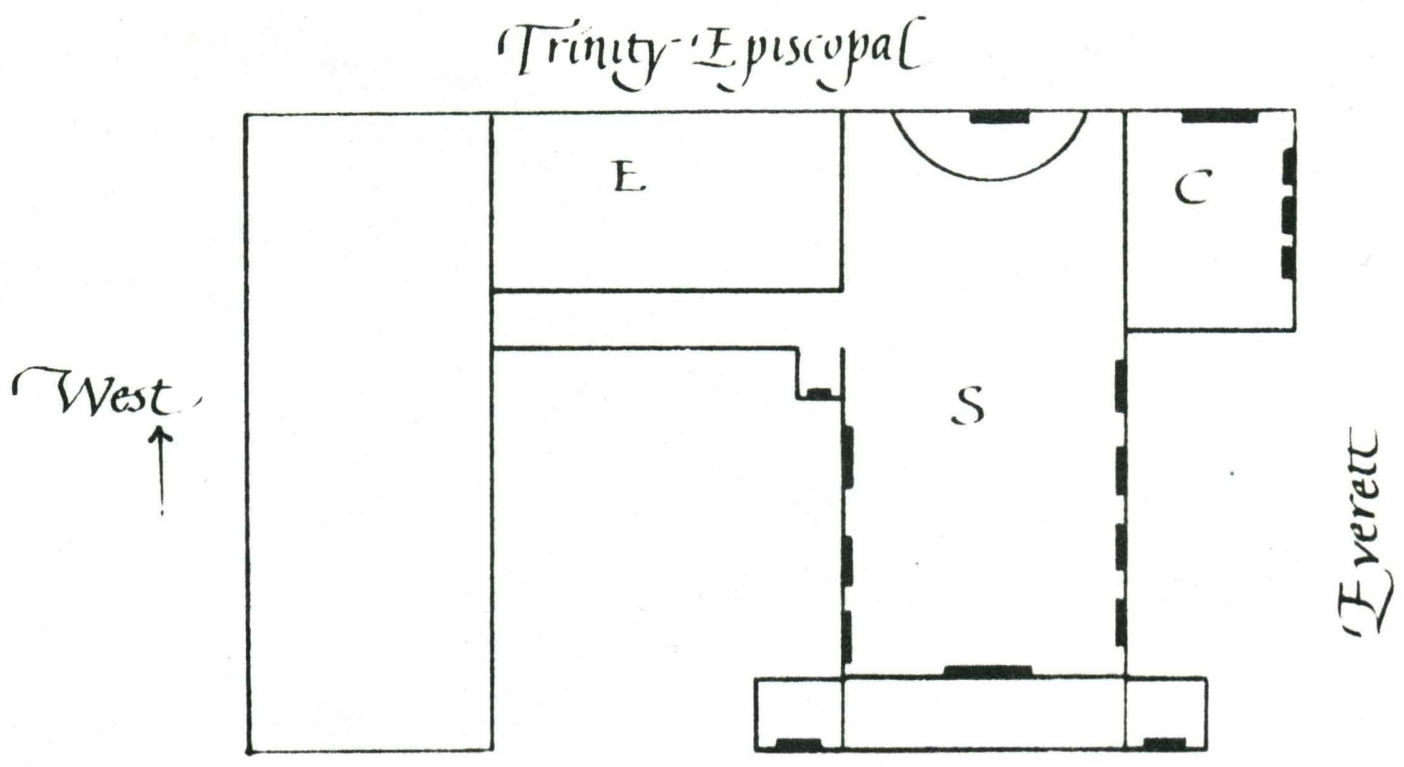

19 th

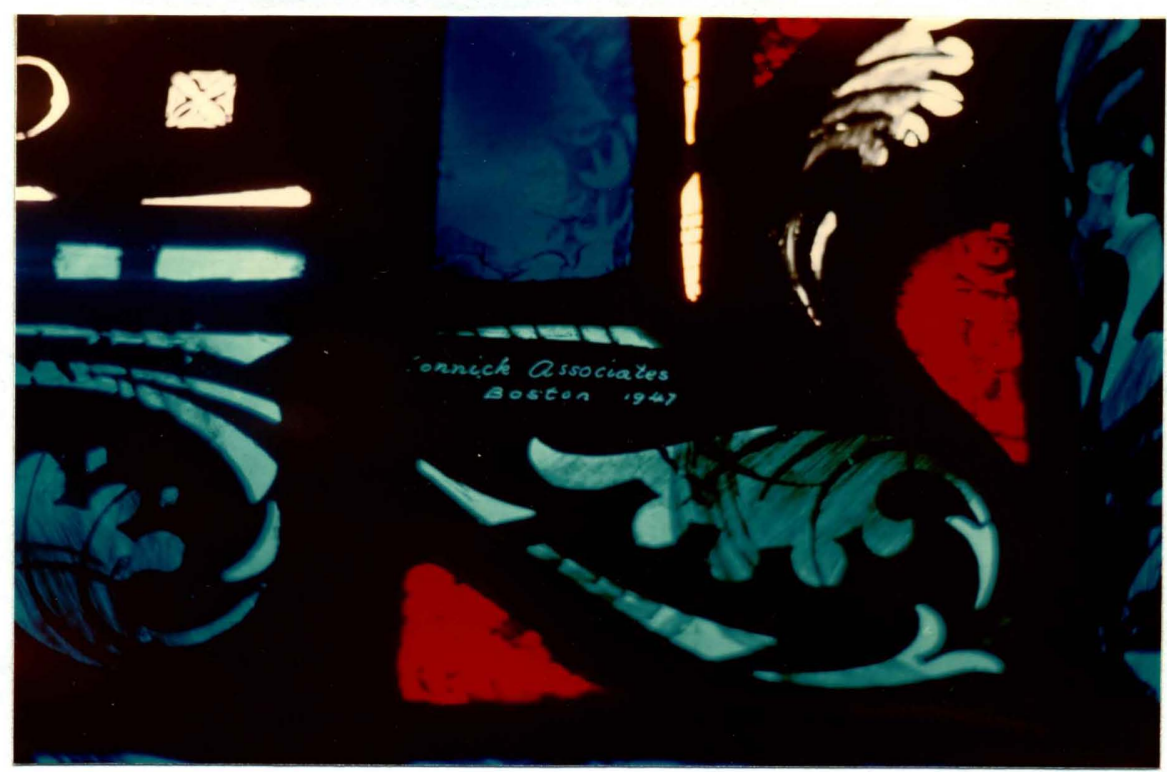

Figure 22 Detail (innick Signature 
The Second Trinity Church, Sixth and Oak, was consecrated in 1873 and destroyed by fire in 1902. However, the window above the altar was saved, and it is now in the east wall above the entrance. ${ }^{13}$ There is no further information available on this window, and it is too inaccessible to study. It does provide a large amount of clear light, necessary for such a dark interior, colored by blues and reds.

The windows in the sanctuary (S) and in the chapel (C) were made by Charles Connick of Boston and completely installed by 1947.14 To quote Mr. Connick,

As in color, so in form, stained glass finds expression in symbolism. It is the underlying ideal, not the surface appearance, the inner reality rather than the exterior manifestation of nature that we seek to represent in design and pattern. We strive to convey the essential image in symbolic form.

Our figures and designs are stylized, but we make use of present-day knowledge of anatomy--designing in expression of our own times.

All of our designs are built on a geometric and rhythmic foundation, much as music is written; and the basic structure supports even the most complicated design. We like a continuous flow of line and form, but we feel that subject should be contained within medallion shapes, with no truncated figures or objects cut off in mid air that might be supposed to continue beyond the confines of the medallion. Unity and integrity of design and form, and an ethereal rather than earthly aspect is our objective.

Our work is symbolic rather than realistic. As great music does not copy the actual sounds of nature, we do not follow her actual forms, but interpret her patterns and significance in terms of symbolism. 15

When the present church was consecrated in 1906, Povey Brothers Studio installed the temporary windows. They can still be seen in the entrance ways, and before 1940, all of the windows were of this style. 


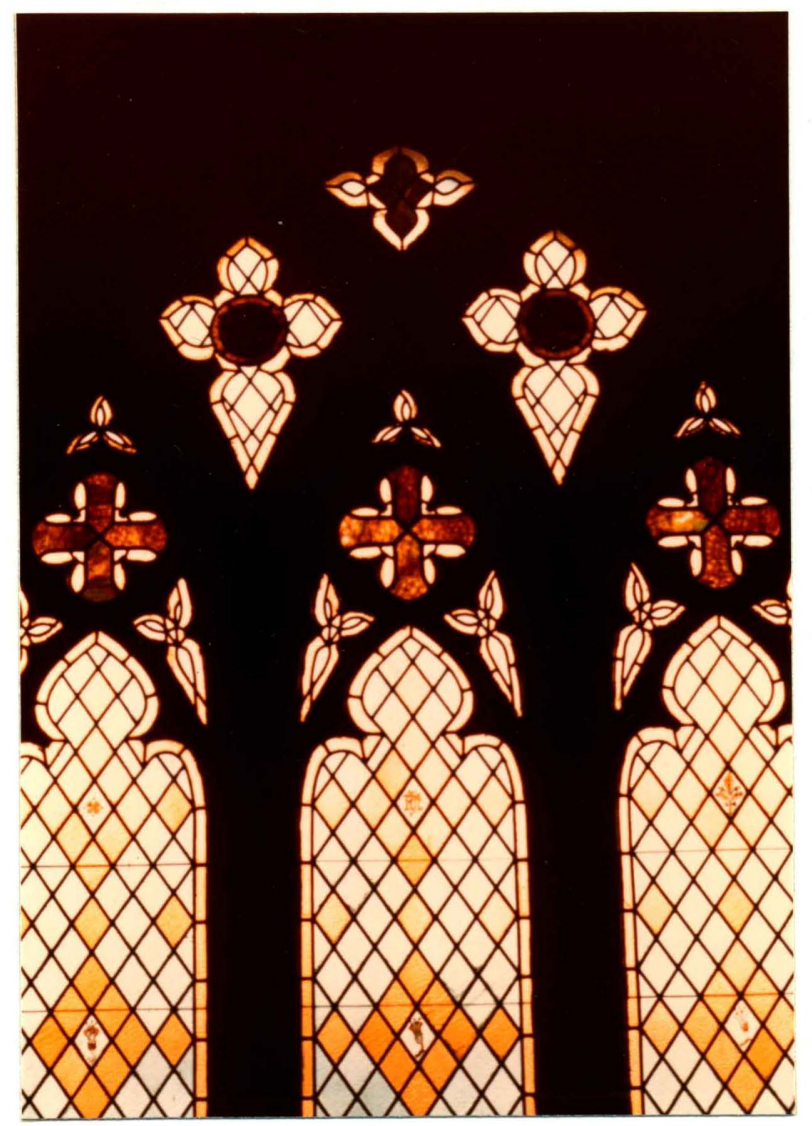

Figure 23. North entrance way. 


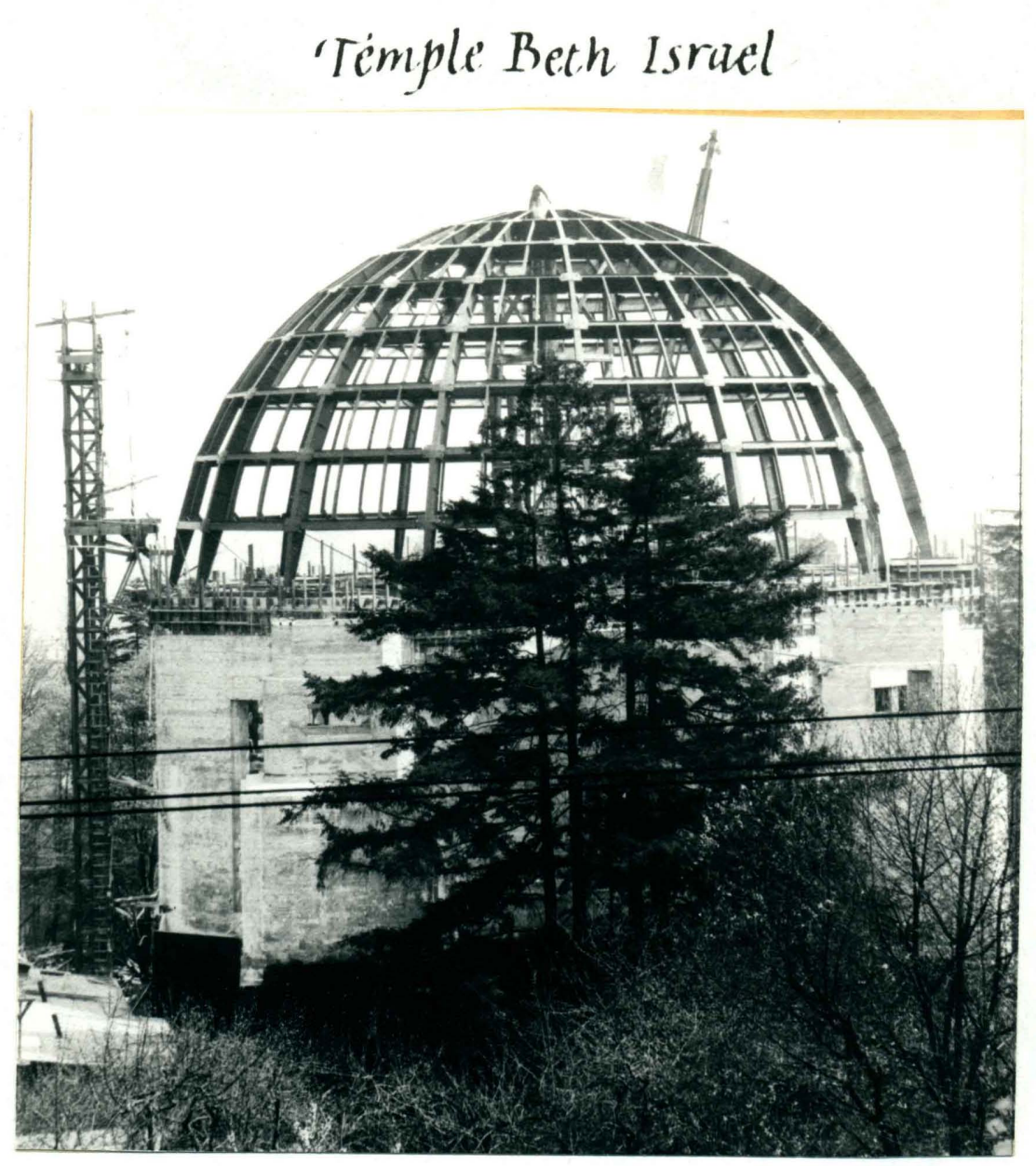

F1gure 24. Exterior.

Temple Beth Israel was dedicated in 1928. The building itself is eclectic in style, with a hundred foot dome covering an octagonal base. All of the windows were made by Albert Gerlach over a twenty year period. The last window was installed in 1946. The general theme of the windows is the major Jewish Holy Days. The upper half of the windows gives reference to biblical passages, and the lower half deplcts the ceremony or symbolic objects assoclated with each holiday.

These are Mr. Gerlach's finest windows, and the only regret is that they are such a great distance from the viewer. The windows have an almost mosaic quality, breaking the light into small, angular pieces of color. The stairwell windows, leading to the balcony, can be viewed more 
closely. The square pleces of clear glass are interlaced with small swirls of color and intricate areas of painting.

The circular window in the west represents the Torah. The intensity of color 18 partly due to the dark recess surrounding 1 t. The design separates the geometry of earth from the more circular areas above. The orange flames of the Torah are actually 11 t by small electric 11ght bulbs.

To quote Mr. Gerlach,

The importance of stained glass in its relation to architecture is not sufficiently appreclated by most people. In a church or cathedral the colored windows absolutely dominate the decorative scheme of the interfor. W1thout its glass the interfor of Chartres would be dignified and noble, but its power to enchant would be gone.16

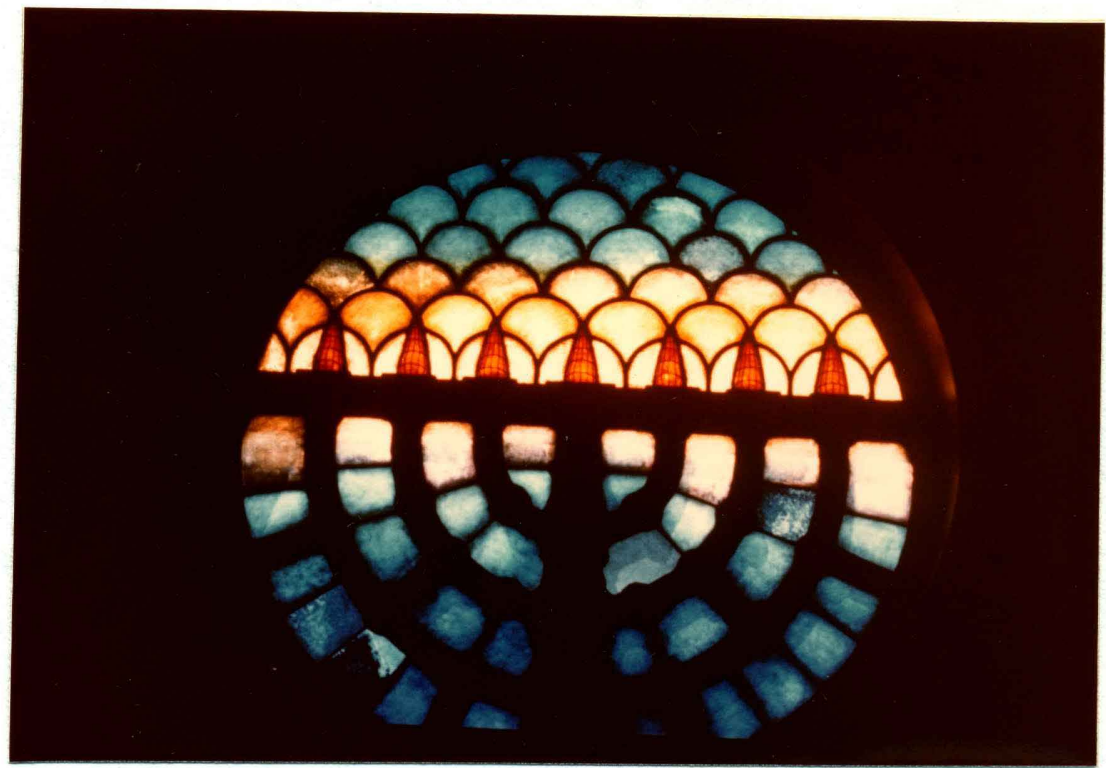

Figure 25. Torah. 
The passing of every hour and every cloud has its effect on the play of subtle color; at no time will any of these magnificent designs look exactly as they were the day or the hour or the cloud before. They are at their most rewarding and mysterious on a cloudy day, for as the light slowly strengthens, semi-hidden or partly percelved detalls suddenly light up and swim out towards you from the depth of a darker color.17 
FOOTNOTES

\section{Section One}

1 Enrico Castelnuovo, "Stained Glass," Encyclopedia of World Art (London: McGraw H111, 1967), p. 350.

2 See Append1x, Composition.

3 John Gilbert Lloyd, Stained Glass in America (Jenkintown, Penn.: Foundation Books, 1963), p. 4 . p. 6 .

4 Herlbert Hutter, Medleval Stained Glass (New York: Crown, 1957),

5 Caryl Coleman, "Stalned Glass," The Catholic Encyclopedia (New York: Encycloped1a Press, 1913), p. 241.

6 The term "grisa11le" now refers to monochromatic windows, which are often decorative.

7 See Append 1x, Theophilus.

8 The Renalssance of the Twelfth Century is such an extensive subject that it is not possible to condense it into such a brief paper; therefore, only the subject of windows w111 be discussed.

9 The term "stained glass" is actually a misnomer, but in common usage it refers to any colored glass window.

10 Abbot Suger, "The Book of Suger," Documentary History of Art, ed. Ellzabeth Holt (New York: Doubleday, 1957), p. 34.

11 William Fleming, Art and Ideas (New York: Holt, Relnhart, and Winston, 1963), p. 249.

12 St. Bernard, "APOLOGIA, To W1111am, Abbot of St. Thierry," Documentary History of Art, ed. El1zabeth Holt (New York: Doubleday, 1957), p. 20.

13 Fleming, p. 276.

14 It was to end in the middle of the fourteenth century, with the beginning of the Hundred Years War and the Black Death.

15 Helen Gardner, Art Through the Ages (New York: Harcourt Brace and World, 1959), p. 202 . 

p. 4 .

16 Otto von Simson, The Gothic Cathedral (New York: Pantheon, 1962),

17 George Duby, Making of the Christian West (Geneva: Skira, 1967), p. 105 .

18 Ib1d., p. 203.

\section{Section Two}

1 Glass Art Magazine, December 1973, p. 25.

2 See Append 1x, Povey.

3 The paint consists of metalic oxides baked onto the surface of the glass. Depending on the craftsmanship, it is considered permanent.

4 See Appendix, First Congregational.

5 See Appendix, Gerlach.

6 "Magazine Section," Sunday Oregonian, 17 April 1927, p. 2.

7 James Canavan, "The Glass Medallions of Carl Paulson," American Art18t, August 1969, p. 23.

8 St. Mathew $6: 28-29$ "And why take ye thought for raiment? Consider the lilies of the fleld, how they grow; they toll not, neither do they spin: and yet I say unto you, that even Solomon in all his glory was not arrayed l1ke one of these."

9 The use of opalescent glass becomes obvious when looking at the windows from the outside.

10 This information was given by Ms. Heneretta Falling during an Intervlew, February 15, 1974.

11 The signature can be found in the lower right hand corner of the central panel.

12 Robert Koch, Louls C. T1ffany, Rebel in Glass (New York: Crown, 1966), p. 58 .

13 Anniversary Celebration (Oregon: Trinity Eplscopal Church, 1951), p. 9 .

14 See Append1x, Trinity Ep1scopal.

15 Charles Connick, "My Philosophy," Stained Glass, ed. Liddall E. Armftage (Massachusetts: C. T. Branf ord, 1959), p. 185. 
16 "Magazine Section," Sunday Oregonian, 17 April 1927, p. 2.

17 Melr Ronnen, "Chagall's Jerusalem Windows," Art Journal, Summer 1962, p. 230. 
Armitage, L1dall E. Sta1ned Glass. Massachusetts: C. T. Branford Co., 1959.

Connick, Charles. Adventures in Light and Color. New York: Random House, 1937.

Duby, George. Making of the Christian West. Geneva: Skira, 1967.

Fleming, William. Art and Ideas. New York: Holt, Reinhart, and Winston, 1963.

Henderson, George. Gothic. Baltimore: Penguin, 1967.

Hutter, Herlbert. Medleval Stalned Glass. Trans. Margaret Shenfield. New York: Crown, 1964.

Hesse, Herman. The Glass Bead Game. New York: Holt, 1969.

Documentary H1story of Art. Ed. E11zabeth Holt. New York: Doubleday, 1957.

Kock, Robert. Lou1s C. Tiffany, Rebel in Glass. New York: Crown, 1966. - Louls C. T1ffany's Glass-Bronze-Lamps. New York: Crown, 1971.

Lloyd, John Gilbert. Stained Glass in America. Jenk1nton, Penn.: Foundation Books, 1963.

Reyntiens, Patrick. The Technique of Stained Glass. New York: WatsorGupt111, 1972.

Sowers, Robert. The L.ost Art. New York: George Wittenborn, 1956. von Simson, 0tto. The Gothic Cathedral. New York: Pantheon, 1962. Welss, Gustav. The Book of Glass. New York: Praeger, 1971. 
APPENDIX 
COMPARISON

Comparison of ancient hand-made glass to 20 th century machine-made window glass. Taken from Samuel R. Scholes Modern Glass Practice, Ch1cago (Industrial Publications, 1952), pages 38 and 40.

1, 2 Colorless glasses from Tel el Amarna, Egypt, 1400 B.C.

3 Window glass from about 900 A.D.

4 European machine-made cylinder 8lass, 1930 A.D.

\begin{tabular}{|c|c|c|c|c|}
\hline & 1 & 2 & 3 & 4 \\
\hline $\mathrm{S}_{2} O_{2}$ & 63.72 & 63.86 & 68.48 & 71.74 \\
\hline $\mathrm{Al}_{2} \mathrm{O}_{3}$ & 1.04 & 0.65 & 0.70 & 1.84 \\
\hline $\mathrm{Fe}_{2} \mathrm{O}_{3}$ & 0.54 & 0.67 & 0.91 & 0.14 \\
\hline $\mathrm{CaO}$ & 9.13 & 7.86 & 5.71 & 14.16 \\
\hline $\mathrm{MgO}$ & 5.20 & 4.18 & 5.28 & - \\
\hline $\mathrm{Na}_{2} \mathrm{O}$ & 20.63 & 22.66 & 14.95 & 11.96 \\
\hline $\mathrm{K}_{2} \mathrm{O}$ & 0.41 & 0.80 & 2.83 & - \\
\hline MnO & - & - & - & - \\
\hline $\mathrm{CuO}$ & - & - & - & - \\
\hline $\mathrm{SO}_{3}$ & - & - & 0.54 & 0.29 \\
\hline $\mathrm{PbO}$ & - & - & 0.95 & - \\
\hline
\end{tabular}


THEOPHILUS

Writings of the tenth century Monk, Theophilus, on composing

stained glass windows. Book II, Chapter XVII, taken from A Documentary

History of Art, E11zabeth Holt, editor, Garden City, New York (Doubleday, 1957), pages 5 and 6.

When you wish to compose glass windows, first make for yourself a flat wooden table, of such breadth and length that you can work upon 1t two portions of the same window [lay every window fleld double on 1t]; and taking chalk, and scraping 1 t with a knife over a11 the table, sprinkle water everywhere, and rub it with a cloth over the whole. And when it is dry, take the dimensions of one portion of the window in length and breadth, marking it upon the table with rule and compass with the lead or $t i n$; and if you wish to have a border in 1t, portray it with the breadth which may please you, and in the pattern you may wish. Which done, draw out whatever figures you will, first with the lead or tin, then with a red or black colour, making all the outlines with study, because 1t will be necessary, when you have painted the glass, that you foln together the shadows and 11ghts according to the [drawing on the] table. Then arranging the different tints of draperies, note down the color of each one in 1ts place; and of any other things which you may wish to paint you will mark the colour with a letter. After this take a leaden cup, and put chalk, ground with water, into 1t: Make two or three pencils for yourself from halr, elther from the tall of the marten, or badger, or squirrel, or cat, or the mane of an ass, and take a plece of glass of whatever kind you 11ke, which is in every way larger than the place upon which it is superposed, and fixing it in the ground of this place, so that you can precelve the drawing upon the table through the glass, so portray with the chalk the outlines upon the glass. And if the glass should be so thick [opaque] that you cannot perceive the IInes which are upon the table, taking white glass, draw upon 1 , and when 1 t is dry place the thick glass on the white, raising it against the 11ght, and as you look through 1t, so portray 1t. In the same manner you w1ll mark out all k1nds of glass. Whether for the face, or in the draperies, in hands, in feet, in the border, or in whatever place you intend to place the colours. 
POVEY

The information below was kindly given during interviews with David Povey's daughter, Mrs. Polly Povey Thompson. It is hoped that sometime In the future more scholarly work can be written on Mr. Povey's windows.

David L. Povey was born in 1865 and died in 1924, the son of a stained glass window maker from St. Louls. David Povey studied art at Cooper Union In New York. He moved to Portland and married the daughter of Peter Hobkirk, a general contractor. Dav1d and his brothers George (b. 1850) and John (b. 1867) establ1shed Povey Brothers Glass Company in 1888, Incorporated in 1893. John worked the shop and George soon left for the Spanish American War.

David Povey was a dynamic, we1l-11ked 1ndividual, as well as a businessman, excellent. craftsman and artist. Although others helped design and make the windows, Mr. Povey personally supervised every aspect of a commission, from design to cholce of color for a leaf and actual Installation.

David Povey felt that everyone knew who made h1s windows, and it was neither hab1t nor tradition to use signatures. By 1923, it became obvious that there was 80 much confusion in authenticating his work of the past thirty years that his last mafor commission, the First Christian Church, 1s signed.

After Mr. Povey's sudden death in 1924, his sons inherited the business. In 1928 it was sold to W. P. Fuller and Company. 
Advertisement from the Portland Architectural Club 2nd Annual

Exhibition Yearbook, 1909.

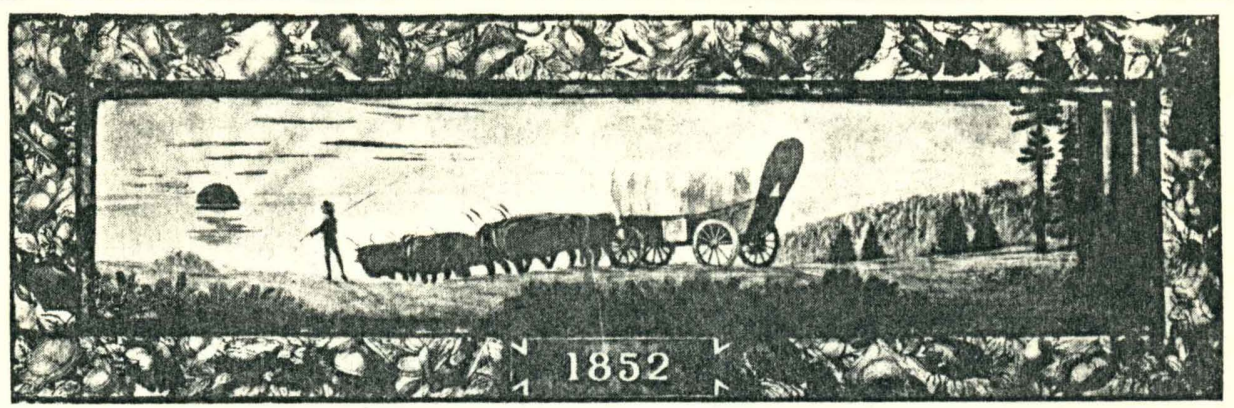

Pioncer Panel in Strowbridge Memorial Window. Designed, Executed and placed in Scottish Rite Cathedral, Portland, Oregon

\section{POVEY BROTHERS} GLASS COMPANY

Designers and Manufacturers of

\section{Artistic 何lass}

For Ecclesiastical and Domestic Purposes

Fifth anid Flanders Sts., Portuani, Oregon 


\section{FIRST CONGREGAT IONAL}

The following is taken from a pamphlet, First Congregational Church, History and Memorials, printed sometime after 1959. It is typical of the historical information avallable on stained glass windows.

\section{WINDOWS IN THE SANCTUARY}

The West Window, dedicated in the fall of 1906, is a memorial to Wilhelmina F. Kribs given by her husband, Frederick A. Kribs. The upper section depicts "The Woman at the Well." The section below the balcony consists of flve panels. The three central ones portray "The Marys' discovery of the Tomb," the south, "Christ bidding farewell to his Mother," and the north, "The Ascension." The coloring runs from dark in the south to light in the north.

The South Window, dedicated in 1910, was given by the Ladies Ald Soclety in Memory of Rev. T. E. Clapp, who concelved and perfected the plans for the church bullding. The 1dea shown is one of ministry. The upper portion portrays the "Blessing of Little Children," depicts seventeen flgures and uses 5,000 pleces of glass. The panels below the balcony show the functions of a true Minister: Teaching, "The Rich Young Ruler," Pastoral, "The Good Shepherd," Preaching, "The Steps of the Temple." In separating panels are the adoring angels.

The North Window 18 a memorial to Samuel Morse Smith given by his wife, Marie A. Smith. It was dedicated in July, 1910. The upper portion 18 a Rose Window. The lower panels consist of a Gothic Cross in the center and on elther side the A, "Alpha" and 0 "Omega."

The window in the North Vestibule, dedicated on Feb. 14, 1932 by the Silver Circle in memory of the departed members of the Circle, represents "The Holy Family."

The window in the South Stalrway in memory of Charles Hansen was given by his family. It was dedicated in 1959.

The window in the South Vestibule in memory of Helen E. Wagner was given by her husband, Lleut. Col. A. A. Wagner. It was dedicated in 1958.

Windows in the Chapel, dedicated on May 24, 1953, are in memory of Delia B. Evans, 1909-1952, given by friends of the church and 
her family; in memory of Frank Hain Johnston, 1890-1952, given by his sons; and in memory of Walter W1lson Crosby, 1886-1932, given by his wife. 
GERLACH

The Information below was given during an interview with Mrs. Albert Gerlach.

Albert Gerlach, born 1884 in Chlcago, was educated in public schools and the Chicago Art Institute. He served a stained glass apprenticeship under A. A. Leyendecker. Before coming to Portland, he was an artist for Giannini and H1lgart Stud1os in Chicago.

After the death of Dav1d Povey, his sons David and Darriel, kept the business going by hiring Albert Gerlach in 1925. When W. P. Fuller bought out Povey Brothers in 1928, Gerlach went to work for Fuller as their head designer. Mr. Gerlach retired in 1950.

Albert Gerlach was very active in the artistic community of Portland. He was twice President of the Oregon Soclety of Artists, and later a director. H1s most outstanding works in Portland are the north window in the First Baptist Church, and all the windows of the Temple Beth Israel Synagogue. 
TRINITY EPISCOPAL

On June 1, 1947, Lansing E. Kempton, D.D., delivered a dedication address for the installation of the west circular window--the last Connick window to be installed. His address was printed by the Church.

Mr. Connick was considered the greatest master of 1 ight and color in stained glass, in our generation. We wished to avold the mistakes made in many churches having badly designed, unrelated, heterogeneous windows, giving the effect of a crazy quilt and stifilng, rather than stimulating, the spirit of worship . . . We also wished to avold the horrible so-called art glass windows of the later 19 th and 20 th century. The art glass windows belonged to that period in which glassmen left their own region of poetic splendor in jewelled design and folned the painters of pictures. The dreamers and poets of light were replaced by literal minded manipulators of glass and paint. The realistic effects of paint stopped the window's play of light and colors became tame. The art glass windows stopped the light like heavy curtains, and burrled the real stained glass craft under an avalanche of mawkish prettiness and sweet ugliness, of ten deplcting waterfalls, sheep, trees, sweet maldens and even the faces of members of one's family on the bodies of angels, madonnas and salnts. From this terrible perlod, Mr. Connick and others have sought to lead us out, and as a result, the United States today can boast of the greatest makers of stained 8lass. The American craftsman have raised the art to new and transcendent heights. 


\section{CRFDITS}

\section{Photography}

Figures 1, 2, 3. From Her 1bert Hutter, Medieval Stained Glass (New York: Crown, 1963), plates 21, 2, 11. 20305 .

Figure 4. Manuscript Department of the British Museum, number

Figures 5, 6, 7. From the slide collection of Ms. Claire Kelly. Thank you, Cla1re.

Flgure 8 . Ben M1lligan hand rolling glass at Portland State University. Author's private collection.

F1gures 10, 12, 13, 14, 16, 18, 20, 21, 22, 23, 25. Author's private collection.

F1gure 9. Oregon H1storical. Soclety, negative 37799.

F1gure 11. Oregon H1storical Soc1ety, negative 37798 .

Figure 15. Oregon Historical Soclety, negative 23683.

Figure 17. Oregon Historical Soclety, negative 28211.

F1gure 19. Oregon Historical Society, negative 37797.

Figure 24. Oregon Historical Society, negative 37800.

\section{Calligraphy}

Special thanks to the pen of Ms. Betty Lou Bennett, whose work provides the human warmth in an otherwise desolate expanse of type.

The first section is written in the Carolingian alphabet, which was in use between the ninth and twelfth centuries. One of the outstanding characteristics of the Caroline was its careful distinction between different styles for different purposes. It developed from an interest in copying early manuscripts especially classical Latin ilterature.

The second section is written in 1 talics, which are based on the letterings of fifteenth century Italian scribes. Italics are in turn indebted to the Carolinglan Miniscule. 